\title{
13. THE FORAMINIFERA AND SOME ASSOCIATED MICROFOSSILS OF SITES 135 TO 144
}

\author{
J. P. Beckmann, Federal School of Technology, Zurich, Switzerland
}

\section{INTRODUCTION AND ACKNOWLEDGMENTS}

A total of 465 samples, all collected on shipboard, were available for examination of the foraminifera and associated microfossils. On the average, this amounts to one sample for slightly less than one meter of recovered core. Most of the washed residues were separated into two fractions (retained in the 80 mesh and 230 mesh sieves). Only a few samples were too hard for conventional washing methods and had to be studied in thin section (Site 139, Core 6; Site 144 , Core 6). A set of charts showing the composition and preservation of the microfauna for each sample, with special emphasis on the foraminifera, has been prepared and is reproduced here on Tables 2 to 11 . These tables also include the determinations of the zones and ages. The figures indicating the planktonic/benthonic ratios and the percentage of foraminifera (of the total fauna in the 80-mesh fraction) are in most cases estimates rather than counts. For some samples, the record of the foraminiferal species has been left incomplete or omitted altogether. Such samples are marked in the last columns ("Remarks") by the letters "P"-partially examined or " $n$ "-not examined. Omissions of this kind will be found in monotonous sequences of rich faunas, or where an occasional sample was poorly preserved. Their purpose was to save time without losing essential data.

Apart from these tables, this volume contains summaries of the foraminifera and some associated microfossils for each core recovered. These summaries, which are both descriptive and interpretative, are incorporated in the appropriate Site Reports (Chapters 2 to 10).

The ages of the foraminiferal faunas recovered on Leg 14 range from the Aptian/Albian to the Quaternary, but the majority of the good assemblages represent the Neogene and the Cretaceous. The best sections for detailed biostratigraphic study are in the Cenomanian-Upper Albian of Site 137, the Upper Cretaceous of Site 144, and the Pliocene-Pleistocene of Site 141. The most completely cored stratigraphic section, with good calcareous microfaunas throughout, is that of Site 144, but since several unconformities were penetrated, the stratigraphic record is not continuous.

The preservation of the faunas is variable. In the majority of the samples, the calcareous shells appear to be more or less affected by solution. In the Pliocene of Site 141 , an excellent example of gradual loss of the calcareous component, involving progressive etching, breaking up, and final disappearance of the foraminifera, can be observed.

Apart from the common planktonic deep-water faunas, a fair number of predominantly benthonic assemblages were encountered. Some of these appear to have been moved downslope from a shallower environment (examples in Sites 135,140 and 142). Other benthonic faunas are entirely noncalcareous and consist essentially of agglutinated deepwater foraminifera (Sites 137, 140 and 141). In the Aptian/Albian faunas (Sites 136, 144), the benthonic element is generally more conspicuous than elsewhere. These may at least in part be autochthonous deposits of the neritic to upper bathyal realm.

In addition to the Leg 14 cores, about thirty samples from piston cores collected by the research vessel Vema were kindly supplied by the Lamont-Doherty Geological Observatory (Palisades, New York). I wish to thank this institution for making available this most useful comparison material. I am also indebted to G.F. Elliott (British Museum, London), A. J. Keij, R. Lagaaji (both Shell-BIPM, Den Haag), and H. J. Oertli (SNPA, Pau, France) for their help in determining the calcareous algal fragments and bryozoans of Site 142, as well as some Cretaceous ostracods of Site 144. Helpful information was received in discussions with M. B. Cita (University of Milano) and F. Roegl (ETH, Zurich). E. A. Pessagno (University of Texas, Dallas) made available his shore lab determinations of samples from Sites 137 and 144. In particular, I wish to thank H. M. Bolli (ETH, Zurich) for his advice on many problems including taxonomy, biostratigraphy and the stratigraphy of the Caribbean area.

\section{BIOSTRATIGRAPHY}

The biostratigraphic subdivision of the Cretaceous, Tertiary and Quaternary, as used in this report, is shown on Table 1. This table also includes references to the definitions of the zones, as well as the age boundaries agreed upon by the shipboard party.

The sequences of foraminiferal zones adopted for the Tertiary is essentially that proposed by Bolli (1957b, c, d, 1966, 1970). It appears that Bolli's scheme can readily be applied to calcareous planktonic faunas from the warm temperate to tropical regions of the Atlantic Ocean. As can be seen on the last column of Table 1, the distribution of the Leg 14 cores among the zones is quite uneven. The maximum is in the Globorotalia margaritae Zone; this could well be an indication that this particular zone represents a longer time interval than most of the others. It may be justified to attempt a further subdivision of this zone.

For the Late Cretaceous, a number of the zones and subzones established by Pessagno (1967) are used. The Early Cretaceous was left unzoned except in Site 137 where the Rotalipora ticinensis Zone could be recognized.

\section{SUMMARY REVIEW OF THE FORAMINIFERAL ASSEMBLAGES}

\section{Eastern Atlantic Sites (135 to 141)}

The tight schedule for drilling these sites left little time for detailed stratigraphic sampling. Nevertheless, on a few 
TABLE 1

Planktonic Foraminiferal Zones to be Used in Leg 14 Initial Report

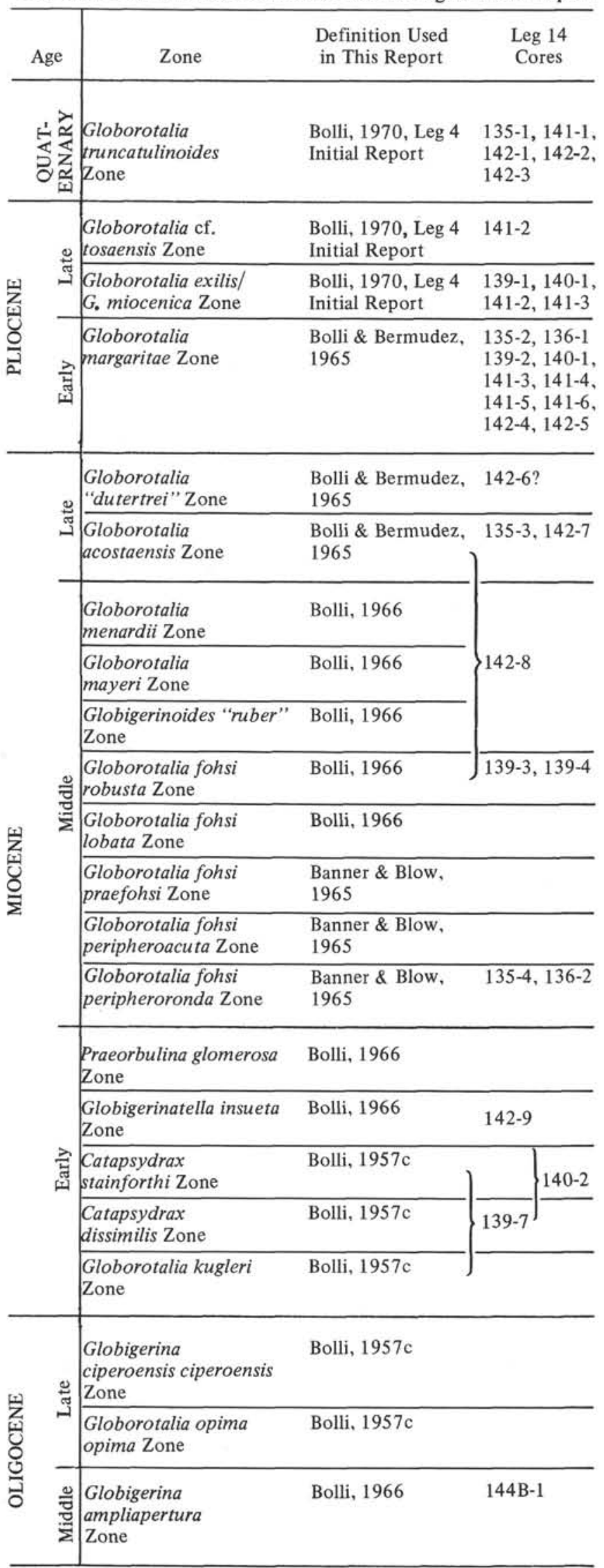

TABLE 1 - Continued

\begin{tabular}{|c|c|c|c|}
\hline Age & Zone & $\begin{array}{l}\text { Definition Used } \\
\text { in This Report }\end{array}$ & $\begin{array}{l}\text { Leg } 14 \\
\text { Cores }\end{array}$ \\
\hline 㐘 & $\begin{array}{l}\text { Cassigerinella } \\
\text { chipolensis/Hastigerina } \\
\text { "micra" Zone }\end{array}$ & Bolli, 1966 & $\begin{array}{l}144 \mathrm{~A}-1 \\
144 \mathrm{~A}-2 \\
144 \mathrm{~B}-2 \\
144 \mathrm{~B}-3\end{array}$ \\
\hline 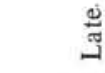 & (Not represented) & & \\
\hline 我 & $\begin{array}{l}\text { Truncorotaloides rohri } \\
\text { Zone }\end{array}$ & Bolli, 1957d & $144 \mathrm{~A}-2$ \\
\hline Ð્1 & $\begin{array}{l}\text { Orbulinoides } \\
\text { beckmanni Zone }\end{array}$ & $\begin{array}{l}\text { Bolli, 1957d (as } \\
\text { Porticulasphaera } \\
\text { mexicana Z.) }\end{array}$ & $144-1$ \\
\hline 全 & (Not represented) & & \\
\hline 乐 & $\begin{array}{l}\text { Globorotalia pseudo- } \\
\text { menardii Zone }\end{array}$ & Bolli, 1957b & $\begin{array}{l}144-2 \\
144 \mathrm{~A}-3\end{array}$ \\
\hline$\sum_{2}^{\infty}$ & (Not represented) & & \\
\hline \multirow{9}{*}{ 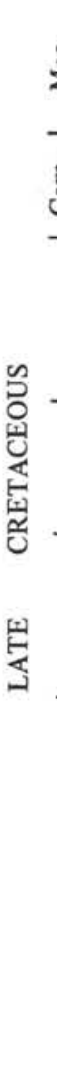 } & $\begin{array}{l}\text { Globotruncana } \\
\text { contusa-stuartiformis } \\
\text { Zone }\end{array}$ & Pessagno, 1967 & $135-7 ?$ \\
\hline & $\begin{array}{l}\text { Globotruncana } \\
\text { fornicata-stuartiformis } \\
\text { Zone }\end{array}$ & Pessagno, 1967 & $\begin{array}{l}144-3 \\
144 \mathrm{~A}-3 \\
144 \mathrm{~A}-4\end{array}$ \\
\hline & $\begin{array}{l}\text { Globotruncana } \\
\text { fornicata Subzone }\end{array}$ & Pessagno, 1967 & \\
\hline & $\begin{array}{l}\text { Marginotruncana } \\
\text { concavata Subzone }\end{array}$ & Pessagno, 1967 & \multirow{2}{*}{$\begin{array}{l}136-5,136-6, \\
136-7 ?, \\
144 A-5 \\
144 A-6\end{array}$} \\
\hline & $\begin{array}{l}\text { Marginotruncana renzi } \\
\text { Zone }\end{array}$ & Pessagno, 1967 & \\
\hline & $\begin{array}{l}\text { Whiteinella archaeo- } \\
\text { cretacea Subzone }\end{array}$ & Pessagno, 1967 & \\
\hline & $\begin{array}{l}\text { Marginotruncana sigali } \\
\text { Subzone }\end{array}$ & Pessagno, 1967 & $137-7,144-4$ \\
\hline & $\begin{array}{l}\text { Rotalipora cushmani - } \\
\text { greenhornensis } \\
\text { Subzone }\end{array}$ & Pessagno, 1967 & $\begin{array}{l}137-8,137-9, \\
137-10, \\
137-11, \\
137-12 \\
\end{array}$ \\
\hline & $\begin{array}{l}\text { Rotalipora evoluta } \\
\text { Subzone }\end{array}$ & Pessagno, 1967 & $\begin{array}{l}137-12, \\
137-13, \\
137-14, \\
137-15 \\
143 \mathrm{~A}-1, \\
144-5\end{array}$ \\
\hline \multirow{2}{*}{ 元兽高 } & $\begin{array}{l}\text { Rotalipora ticinensis } \\
\text { ticinensis Zone }\end{array}$ & Bolli, 1957a & $\begin{array}{l}\text { 137-16, } \\
137-S W 1\end{array}$ \\
\hline & (Undifferentiated) & & $\begin{array}{l}136-8,144-6 \\
144-7,144-8\end{array}$ \\
\hline
\end{tabular}


occasions where efforts were made not to miss important geophysical horizons or the acoustic basement, good sequences of continuous or nearly continuous cores were recovered (Sites 136, 137, 141). In Site 137 (Cores 7 to 16, SW. Core 1), we found a series of excellently preserved Globotruncanidae through the Cenomanian-Late Albian, and from Site 141 (Cores 1 to 7 ) we have an equally good record of the Pleistocene and Pliocene in calcareous planktonic facies. The wide average core spacing of about 100 meters in some sites $(135,138,139)$ makes it difficult to summarize the geological history of the area but nevertheless a few general trends appear to be indicated by the available data:

a. Moderately calcareous faunas, sometimes with a conspicuous benthonic element, are found in late Early Cretaceous time (example: Site 136, Core 8).

b. Rich planktonic faunas in the Cenomanian (Site 137) are followed by impoverished (partially dissolved?) planktonic faunas of the Turonian and lower Senonian (Sites 136, 137).

c. From the latest Cretaceous through the PaleoceneEocene-Oligocene, we have essentially noncalcareous (deep-sea?) clay deposition (Sites 138,140 ) or even nondeposition (Site 136).

d. In the Miocene, calcareous faunas reappear at some sites (at least Sites 135, 136, 139, 140). Usually, the plankton is partially dissolved. Displaced faunas derived from shallower water are found at Sites 139 and 140 .

e. In the Pliocene and Quaternary, planktonic foraminifera are in most cases common and fairly well preserved, similar to those of the present day.

On the whole, the sequence of events is comparable to that inferred by Cita (1970) for the North Atlantic sites of Leg 2. In general, the faunas of Leg 14 appear to reflect a distinctly deeper water environment than the contemporaneous faunas known from the West African coast (Reyre, 1966). There are a few intervals, however, where the onshore and offshore faunas seem to have much in common (see Lehmann, 1966, for the Cretaceous; Colom, 1965, for the Miocene Globorotalia fohsi robusta Zone). The Eastern Atlantic along the African coast should certainly be an excellent area for studying the effects of climatic changes on the microfaunas, particularly during the Pliocene and Pleistocene. The available samples are too scattered to obtain a reliable pattern. Still, the Leg 14 cores seem to confirm that Globorotalia miozea (Site 135 only) is typical of temperate waters. The more tropical species Globorotalia exilis and $G$. miocenica were found only as far north as Site 139. The northward extension of Globorotalia multicamerata and Sphaeroidinella dehiscens goes as far as Site 140. Pulleniatina is confined to Site 141.

\section{Western Atlantic Sites (142 to 144)}

For the biostratigrapher, Site 142 (Quaternary to Miocene) and the combined Sites 143-144 (Oligocene to Cretaceous) turned out to be a most rewarding source of data. The microfaunas of Site 142 are the reflection of a highly complex sedimentary history (see Table 9). The influx of terrestrial and near-shore material in the early Quaternary, the common redeposited shallow-water fossils in the Pliocene-Late Miocene, and the frequent association of strongly etched and perfectly preserved planktonic foraminifera indicate intensive mixing of material from different sources. Most of these irregularities can be explained by the location of this site off the Amazon Delta and near a submarine ridge (Cearà Rise). In addition, the occurrence of Bryozoans and of many calcareous algal fragments suggests the presence of reef flats or islands at certain times.

After abandonment of the unsuccessful Site 143, extensive coring was carried out at Site 144 from the Oligocene to the Middle Eocene and again from the Paleocene to the Aptian/Albian. Although the section is calcareous and predominantly pelagic, several distinct unconformities were penetrated (Eocene/Oligocene and Cretaceous/Tertiary boundaries). The stratigraphic section and the sequence of microfaunas are similar to those of the Eastern Venezuela basin (Jenks, 1956; Lexico Estratigrafico de Venezuela, 1970; Metz, 1968) and of South Trinidad (Kugler and Bolli, 1967).

\section{Preservation of the Microfaunas and Calcium Carbonate Solution}

The preservation of the microfaunas of Leg 14 varies from excellent to very poor. The best preserved faunas are found not only in Quaternary but also in some relatively old sediments (Cenomanian pelagic marls of Site 137; benthonic faunas in the Aptian/Albian of Sites 136 and 144). Excellent preservation is also a characteristic of some displaced microfossils; these were most probably transported in suspension and rapidly buried, and thus escaped both abrasion and solution. Typical examples can be seen in Site 135 (Core 7), Site 140 (Cores A-1 and 2), and Site 142 (Cores 1-3, 5, 6).

The most universal factor which influences the preservation of the calcareous microfossils is certainly the solution of calcite in the deep sea. On Tables 2 to 11 , the visible solution effects are recorded for each sample in qualitative terms (very strong, strong, moderate, weak). A more quantitative approach (see, for instance, the solution index in Berger and Parker, 1970) would certainly be desirable, but criteria other than faunal diversity should probably be sought as a measure of solution in fossil material.

A complete sequence of gradual destruction of calcareous shells through progressive solution can be seen in the Pliocene of Site 141 (Cores 4 to 7, particularly). An almost identical process has already been observed in the nearby DSDP Site 12 (Leg 2); it is described in detail by Cita (in press). There can be no doubt that a similar process also acted on older faunas. In the Cenomanian of Site 137, there are a few almost noncalcareous levels interbedded with marls containing perfectly preserved pelagic foraminifera. Yet it is apparently unusual in pre-Neogene sediments to see such good sequences of progressive etching and breaking up of shells as in Site 141. The writer has observed similar differences in the solution pattern between the Paleogene and Neogene faunas of the Central Pacific (DSDP Leg 8).

Very poorly preserved shells of foraminifera and radiolarians (mostly internal casts) are typical of some Upper Cretaceous rocks, particularly at Site 136. In this 
this case, factors other than great water depth may be responsible, since the samples are rich in volcanogenic components.

\section{Displaced Faunas}

Microfossil assemblages which appear to be partially or even totally allochthonous are fairly common at some of the Leg 14 sites. For descriptions of the lithology and fossil content of such heterogeneous intervals, the reader is referred to the Site Reports of Sites 135, 139, 140 and 142, and also to Tables 2, 6, 7 and 9 in this chapter. Plant fragments and abundant quartz sand are often associated with the displaced microfaunas. In some cases, such faunas may be found interbedded in a noncalcareous red clay sequence (Site 135, Core 7, Center Bit sample). More commonly, however, the allochthonous character is indicated by the coexistence of two or more preservations or colors in one sample, or by the presence of typical shallow water fossils. A typical case is Core 5 of Site 142 with its association of strongly etched planktonic foraminifera (presumably the only autochthonous component) with perfectly preserved, thin-walled globigerinids, calcareous algae, bryozoans and plant remains. Examples of redeposited shallow-water fossils are the Upper Cretaceous orbitoids of Site 135 , or the barnacle plates and associated benthonic foraminifera (Ammonia, Pararotalia, Amphistegina) in the Miocene of Site 140. Displaced planktonic assemblages are usually recognized by their perfect preservation (Site 142, Cores 1-3, 5, 6) or the predominance of one size grade (Site 135, Core 7).

A combined sedimentological and micropaleontological study of these heterogeneous rocks by members of the shipboard party is planned for later publication.

\section{Samples of Vema Piston Cores Located Near Leg 14 Sites}

Samples from the following Vema piston core stations were also made available for study:

V-27-162 (near Site 136)

V-27-167 (between Sites 137 and 138)

V-23-98 (near Site 139)

V-23-99 (near Site 140)

V-26-41 (near Site 141)

V-24-258, V-25-49, V-25-62, V-25-63, V-25-64 (all near

Site 142)

V-25-73, V-25-74, V-25-75, V-25-76, V-25-77 (all near Sites $143,144)$

These samples are a most valuable addition to the Leg 14 cores, since coring operations from the Challenger normally started some distance below the sea floor. They made it possible to compare the fossil faunas recovered by the Glomar Challenger with recent to Late Pleistocene faunas deposited in the same area and at a similar water depth. All available piston core samples (except V-25-62) are of Quaternary age. In most cases the composition and preservation of their faunas are as expected at their respective locations, but there are a few interesting exceptions:

a. V-27-167, collected in the area between Sites 137 and 138 at a water depth of 5099 meters, contains a fairly rich calcareous planktonic assemblage at the sea floor (sample at 2 to 4 centimeters), and in some deeper zones as well $(280,292.5$, and 300 centimeters). The foraminiferal shells in the sea-floor sample, and particularly in the foraminiferal marl at 292.5 centimeters, are much better preserved than one would expect at such a water depth. In the remaining two samples ( 280 and 300 centimeters) solution effects are much stronger. The fauna at 292.5 centimeters may well be redeposited (the core description mentions some slight grading). The highest cores of Sites 137 and 138 are practically noncalcareous, but a few planktonic foraminifera derived from the Quaternary were found as contamination in Core 1 of Site 138.

b. V-23-99, near Site 140, contains abundant pelecypod shells at 77 to 79 centimeters. These are mostly etched or abraded, but at the same time are associated with abundant well-preserved planktonic foraminifera. Similar mixed assemblages were found in the Miocene of the nearby Site 140 .

c. The cores recovered from the abyssal plain near Site 141 (V-24-258, V-25-49, V-25-64) are remarkably different from the Pleistocene cores of Site 142. The latter contain quartz sand, plant fragments, and some shallow water fossils, whereas the piston core samples are practically free of terrigeneous detritus.

The faunas of Piston Core V-25-62, located near the crest of the Ceara Rise, are of Miocene age (Globorotalia fohsi peripheroacuta Zone near the top, Praeorbulina glomerosa Zone near the bottom at 340 to 343 centimeters).

\section{SPECIES REFERENCE LIST}

The majority of the species mentioned in this report are well known in the recent literature. For descriptions, illustrations and synonymies, the reader is referred to the following papers and monographs:

Planktonic foraminifera: Blow (1969)

$$
\text { Bolli (1957b, c, d; 1959) }
$$

Pessagno (1967)

Benthonic foraminifera: Beckmann (1954)

Frizzell (1954)

Simon et al. (1962)

References to the species not included in these six publications are given below, together with some additional comments.

\section{Planktonic Species}

Chiloguembelina cubensis (Palmer).

Gümbelina cubensis Palmer, 1934, Mem. Soc. Cubana Hist. Nat., Vol. 8, p. 74, textfigs. 1 -6.

Chiloguembelina martini (Pijpers).

Textularia martini Pijpers, 1933, Geogr. Geol. Med., Univ. Utrecht, Phys. Geol. Reeks, no. 8, p. 57, figs. 6-10.

Globigerinelloides breggiensis (Gandolfi).

Anomalina breggiensis Gandolfi, 1942, Riv. Ital. Paleontol. Strat., mem. 4 , p. 102 , textfig. 34 (1-4); pl. 3, fig. 6; pl. 5, fig. $3 ;$ pl. 9 , fig. $1 ;$ pl. 13 , figs. 7,8 . Holotype refigured by Caron and Luterbacher (1969). 
Globorotalia crassaformis A.

Globorotalia crassaformis A, Bolli, 1970, DSDP Initial Reports, vol. IV, p. 580 , pl. 4 , figs. 17.20. This is probably a good marker for the base Pleistocene- top Pliocene.

Globorotalia crassata (Cushman).

Pulvinulina crassata Cushman, 1925, Bull. Am. Assoc. Petrol. Geol., vol. 9, p. 300, pl. 7, fig. 4. Lectotype designated by Bandy, 1964, Contrib. Cushman Foun. Foram. Res. vol. 15, p. 34.

Globorotalia margaritae Bolli and Bermudez.

A small and large variety have been distinguished in the present report. The former appears to be characteristic of the lower part of the G. margaritae Zone, the latter is confined to the upper part (see also Bolli, 1970, p. 581). A taxonomic revision and biostratigraphic reevaluation of this species is now under way (H. M. Bolli, M. B. Cita; personal communication) and may lead to a more refined subdivision of the Early Pliocene.

\section{Globorotalia pertenuis Beard.}

G. pertenuis Beard, 1969, Trans. Gulf Coast Assoc. Geol. Soc., vol. 19, p. 552, pl. 1. figs. 1-6; pl. 2, figs. 5, 6; pl. 3, fig. 4. This species may correspond to the informal category G. exilis A of Bolli (1970). It differs from $G$. exilis Blow in having more chambers, which are also more radially elongated, in the final whorl.

Globorotalia pomeroli Tourmarkine and Bolli.

G. cerroazulensis pomeroli Tourmarkine and Bolli, 1970, Rev. Micropaleontol., vol. 13, p. 140, pl. 1, figs. 10-18.

Globorotalia pseudomiocenica Bolli and Bermudez.

G. pseudomiocenica Bolli and Bermudez 1965, p. 140, pl. 1, figs. 13-15.

Globorotalia cf. tosaensis Takayanagi and Saito.

The distribution of this species in the Atlantic Ocean is much more erratic than in the Pacific. Also it appears to be rather rare and is certainly not a good species for defining a zone. There are a few specimens in Site 141 which resemble the figures given by Bolli (1970; pl. 3, figs. 16-21).

\section{Globorotalia cf. tumida/plesiotumida.}

Here are included specimens which are usually slightly smaller and more delicately built than $G$. tumida. Normally, they are found together with $G$. margaritae. Some of the specimens are very close to the holotype of $G$. plesiotumida Blow, but the variability and distribution of this species are not adequately known.

Globorotalia wilsoni (Cole).

Globigerina wilsoni Cole, 1927, Bull. Am. Paleontol., vol. 14 , no. 51 , p. 34 , pl. 4 , figs. 8,9 .

Globotruncana caliciformis Vogler.

G. linnei d'Orbigny calciformis Vogler, 1941, Palaeontogr., Suppl. Bd, 4, Abt. 4, p. 288, pl. 24, fig. 23.

Globotruncana tricarinata (Quereau).

Pulvinulina tricarinata Quereau, 1893, Beitr. Geol. Karte Schweiz, N.F. 33, p. 89, pl. 5, fig. 3.

Globotruncana ventricosa primitiva Dalbiez.

G. (Globotruncana) ventricosa primitiva Dalbiez, 1955, Micropaleontol., vol. 1, p. 171, textfig. 6 .
Hantkenina longispina Cushman.

H. longispina Cushman, 1924, Proc. U.S. Nat. Museum, vol. 66 , Art. 30, p. 2, pl. 2, fig. 4.

Hedbergella trocoidea (Gandolfi).

Anomalina lorneiana (d'Orbigny) var. trocoidea Gandolfi, 1942, Riv. Ital. Paleontol., Strat., mem. 4, p. 99, pl. 2, fig. 2; pl. 4, figs. 2, 3; pl. 13, figs. 2, 5. Lectotype described and figured by Caron and Luterbacher (1969).

Heterohelix cf. frizzelli (Kavary).

"Pseudogumbelina" frizelli Kavary, 1963, Bull. Univ. Missouri School Mines etc., Tech. Ser., no. 102, p. 66, pl. 13 , figs. 19,20 . This name refers here to short specimens which consist essentially of two relatively large chambers with only a very small, more or less pointed initial stage. Kavary's description does not go into much detail and seems to overlap with that of another new species, Pseudotextularia (?) reissi.

Rotalipora balernaensis Gandolfi.

R. appenninica balernaensis Gandolfi, 1957, Contr. Cushman Found. Foram. Res., vol. 8, p. 60, pl. 8, fig. 3.

Rotalipora brotzeni (Sigal).

Thalmanninella brotzeni Sigal, 1948, Rev. Inst. Fr. Petr., vol. 3, p. 101, pl. 1, fig. 5; pl. 2, figs. 6, 7 .

Rotalipora reicheli (Mornod).

Globotruncana (Rotalipora) reicheli Mornod, 1950, Ecology. Geol. Helv., vol. 42 , p. 583 , textfig. 5 (4), textfig. 6 (1-6); pl. 25, figs. 3,4 .

Rotalipora ticinensis (Gandolfi).

Globotruncana ticinensis Gandolfi, 1942, Riv. Ital. Paleontol. Strat., mem. 4, p. 113, textfig. 39; pl. 2, fig. 3; pl. 4, figs. $10,11,23$; pl. 5 , figs. 2,4 ; pl. 8 , figs. $4-7$; pl. 12 , fig. 1 ; pl. 13 , figs. $11,12,14$. Holotype redrawn by Caron and Luterbacher (1969).

Ticinella raynaudi digitalis Sigal.

T. raynaudi var. digitalis Sigal, 1966, Ecolog. Geol. Helv., vol. 59 , p. 202 , pl. 6 , figs. 6-8.

\section{Benthonic Species}

Ammonia beccarii (Linné) s.1.

Nautilus beccarii Linné, 1758, Syst. Nat., ed. 10, p. 710. See also Loeblich and Tappan (1964, p. 607).

Amphistegina cubensis Palmer.

A. cubensis Palmer, 1934, Mem. Soc. Cubana Hist. Nat., vol. 8 , p. 256 , pl. 15 , fig. 2 ; textfigs. 16,17 .

Aragonia velascoensis (Cushman).

Textularia velascoensis Cushman, 1925, Contr. Cushman Lab. Foram. Res., vol. 1, p. 18, pl. 3, fig. 1.

Bandyella greatvalleyensis (Trujillo).

Pleurostomella greatvalleyensis Trujillo, 1960, J. Paleontol., vol. 34, p. 345, pl. 50, figs. 5, 6 .

Bolivinoides delicatulus Cushman.

B. decorata (Jones) var. delicatula Cushman, 1927, Contr. Cushman Lab. Foram. Res., vol. 2, p. 90, pl. 12, fig. 8.

Bulimina arkadelphiana Cushman and Parker.

B. arkadelphiana Cushman and Parker, 1935, Contr. Cushman Lab. Foram. Res., vol. 11, p. 96, pl. 15, figs. 1, 2. 
Clavulina arenata Cushman.

C. arenata Cushman, 1933, Contr. Cushman Lab. Foram. Res., vol. 9, p. 54, pl. 6, fig. 5.

Clavulina gaultina Morozova.

C. gaultina Morozova, 1948, Bull. Soc. Nat. Moscow, N.S. 53, Sect. Geol., 23, p. 36, pl. 1, fig. 4. Reference in Noth (1951).

Elphidium macellum (Fichtel and Moll).

Nautilus macellus Fichtel and Moll, 1798, Test. Micr., p. 66 , pl. 10, figs. e-k.

Gavelinella schloenbachi (Reuss).

Rotalia schloenbachi Reuss, 1863, Sitzber. K. Akad. Wiss. Wien, Math. Naturw. Cl., vol. 46, pl. 84, pl. 10, fig. 5.

Glomospira gordialis (Jones and Parker).

Trochammina squamata Jones and Parker var. gordialis Jones and Parker, 1860, Quart. J. Geol. Soc. London, vol. 16, p. 304. Parker and Jones, 1865, Phil. Trans., vol. 155, p. 408 , pl. 15 , fig. 32 .

Gyroidina tenera (Brady).

Truncatulina tenera Brady, 1884, Rept. Voy. Challenger, Zool., vol. 9, p. 665, pl. 95, fig. 11.

Haplophragmoides foliaceus (Brady).

Haplophragmium foliaceum Brady, 1881, Quart. J. Micr. Soc., vol. 21, p. 50. Brady. 1883, Rept. Voy. Challenger, Zool. vol. 9, p. 304, pl. 33, figs. 20-25.

Lenticulina dubiensis (Berthelin).

Cristellaria dubiensis Berthelin, 1880, Mém. Soc. Géol. France, ser. 3, Vol. 1, no. 5, p. 52, pl. 3, fig. 24.

Lenticulina saxocretacea Bartenstein.

L. saxocretacea Bartenstein, 1954, Senckenb, Lethea, vol. 35 , p. 45 . For Cristellaria subalata Reuss, 1863 (non Reuss, 1854).

Lenticulina secans (Reuss).

Cristellaria secans Reuss, 1860, Sitzber. K. Akad. Wiss. Wien, Math. Naturw. Cl., vol. 40, p. 214, pl. 9, fig. 7.

Lenticulina subangulata (Reuss).

Cristellaria subangulata Reuss, 1863, Sitzber. K. Akad. Wiss. Wien, Math. Naturw. Cl., vol. 46, p. 74, pl. 8, fig. 7.

Lingulina loryi (Berthelin).

Frondicularia loryi Berthelin, 1880, Mém. Soc. Géol. France, ser. 3 , vol. 1 , no. 5 , p. 80 , pl. 4 , fig. 5 .

Marssonella kummi Zedler.

M. kummi Zedler, 1961, Palaeontol. Zeitschr., vol. 35, p. 31 , pl. 7, fig. 1 .

Pyramidina szajnochae (Grzybowski).

Verneuilina szajnochae Grzybowski, 1896, Akad. Um. Krakow, Wydz. Mat.-Przyr., Rozpravy, ser. 2, vol. 10, p. 287, pl. 9, fig. 19.

Spiroplectammina anceps (Reuss).

Textularia anceps Reuss, 1845, Verst. Boehm. Kreide, pt. 1, p. 39 , pl. 8 , fig. 79 ; pl. 13 , fig. 78 .

Spiroplectammina carinata (d'Orbigny).

Textularia carinata d'Orbigny, 1846, Foram. Foss. Bass. Tert. Vienne, p. 247, pl. 14, figs. 32-34.
Spiroplectammina mexiaensis Lalicker.

S. mexiaensis Lalicker, 1935, Contr. Cushman Lab. Foram. Res., vol. 11, p. 43, pl. 6, figs. 5, 6.

Tritaxia tricarinata (Reuss).

Textularia tricarinata Reuss, 1845, Verst. Boehm. Kreide, pt. 1 , p. 39 , pl. 8 , fig. 60 .

Trochamminoides coronatus (Brady).

Trochammina coronata Brady, 1879, Quart. J. Micr. Sci., vol. 19, p. 58, pl. 5, fig. 15. Brady, 1884, Rept. Voy. Challenger, Zool., vol. 9, p. 340, pl. 40. figs. 10-12.

Uvigerina asperula Czjzek.

U. asperula Czjzek, 1848, Haidingers Naturw. Abhandl., Bd. 11 , p. 146 , pl. 13 , figs. 14,15 .

\section{Problematica}

Coptocampylodon lineolatus Elliott.

C. lineolatus Elliott, 1963, Palaeontology, vol. 6, p. 297, pl. 46, fig. 4, 5, 6, 8; pl. 48, fig. 2 .

\section{REFERENCES}

Banner, F. T. and Blow, W. H., 1960. Some primary types of species belonging to the Superfamily Globigerinaceae. Contrib. Cushman Found. Foram. Res. 11, 1. , 1965. Progress in the planktonic foraminiferal biostratigraphy of the Neogene. Nature. 208 (5016), 1164.

Beckmann, J. P., 1954. Die Foraminiferen der Oceanic Formation (Eocaen-Oligocaen) von Barbados, Kl. Antillen. Ecolog. Geol. Helv. 45 (1953), 301.

Berger, W. H. and Parker, F. L., 1970. Diversity of planktonic foraminifera in deep-sea sediments. Science. 168,1345 .

Blow, W. H., 1969. Late Middle Eocene to Recent planktonic foraminiferal biostratigraphy. Proc. First Intern. Conf. Plank. Microfossils, Geneva 1967. 1, 199.

Bolli, H. M., 1957a. The genera Praeglobotruncana, Rotalipora, Globotruncana, and Abthomphalus in the Upper Cretaceous of Trinidad, B.W.I. U.S. Nat. Museum Bull. 215, 51.

, 1957b. The genera Globigerina and Globorotalia in the Paleocene-Lower Eocene Lizard Springs Formation of Trinidad, B.W.I. U.S. Nat. Museum Bull. 215, 61. , 1957c. Planktonic foraminifera from the Oligocene-Miocene Cipero and Lengua Formations of Trinidad, B.W.I. U.S. Nat. Museum Bull. 215, 97. , 1957d. Planktonic foraminifera from the Eocene Navet and San Fernando Formations of Trinidad, B.W.I. U.S. Nat. Museum Bull. 215, 155.

, 1959. Planktonic foraminifera from the Cretaceous of Trinidad, B.W.I. Bull. Am. Paleontol. 39 (179), 258.

, 1966. Zonation of Cretaceous to Pliocene marine sediments based on planktonic foraminifera. Bol. Inform. Asoc. Venez. Geol. Min. Petr. 9, 3 .

1970. The foraminifera of Sites 23-31, Leg 4. In Bader, R. G. et. al., 1970, Initial Reports of the Deep Sea Drilling Project, Volume IV. Washington (U.S. Government Printing Office), 577.

Bolli, H. M. and Bermudez, P. J., 1965. Zonation based on planktonic foraminifera of Middle Miocene to Pliocene 
warm-water sediments. Bol. Inform. Asoc. Venez. Geol. Min. Petr. 8, 121.

Caron, M. and Luterbacher, H. P., 1969. On some type specimens of Cretaceous planktonic foraminifera. Contrib. Cushman Found. Foram. Res. 20, 23.

Cita, M. B., 1970. Observations sur quelques aspects paléoécologiques de sondages subocéaniques effectués dans l'Atlantique Nord. Rev. Micropaleontol. 12, 187.

Cita, M. B. (in press). Biostratigraphy, chronostratigraphy and paleoenvironment of the Pliocene of Cap Verde (North Atlantic). Rev. Micropaleontol. 14 (5).

Colom, G., 1965. Micropaleontologia del Sahara español. Estudios Geol. 21, 167.

Frizzell, D. L., 1954. Handbook of Cretaceous foraminifera of Texas. Bur. Econ. Geol., Univ. Texas, Rept. Invest. 22, $232 \mathrm{pp}$.

Jenks, W. F. (ed.), 1956. Handbook of South American geology. Geol. Soc. Am., Mem. 65, 378 pp.

Kugler, H. G. and Bolli, H. M., 1967. Cretaceous biostratigraphy in Trinidad, W. I. Bol. Inform. Asoc. Venez. Geol. Min. Petr. 10, 209.

Lehmann, R., 1962. Etude des Globotruncanidés du Cretacé supérieur de la Province de Tarfaya (Maroc occidental). Notes Serv, géol. Maroc. 21, 133.
1966. Les foraminiféres pélagiques du Crétacé du bassin côtier de Tarfaya. Notes Mém. Serv. géol. Maroc. 175, 153.

Lexico Estratigrafico de Venezuela (Segunda Ed.), 1970. Bol. Geol., Publ. Especial. 4, 756 p.

Loeblich, A. R. and Tappan, H., 1964. Protista 2: Sarcodina, chiefly "Thecamoebians" and Foraminiferida. Treatise Invert. Paleont., C, $900 \mathrm{pp}$.

Metz, H. L., 1968. Biostratigraphic and geologic history of extreme northeastern Serrania del Interior, State of Sucre, Venezuela. Trans. Fourth Caribbean Geol. Conf., Trinidad, 1965. 275.

Noth, R., 1951. Foraminiferen aus Unter- und Oberkreide des oesterreichischen Anteils an Flysch, Helvetikum and Vorlandvorkommen. Jahrb. Geol. Bundesanst, Sonderband. 3, $91 \mathrm{pp}$.

Pessagno, E. A., 1967. Upper Cretaceous planktonic foraminifera from the western Gulf Coastal plain. Paleontogr. Am. 5 (37), 245.

Reyre, D. (ed.), 1966. Sedimentary basins of the African coasts. IUGS, Assoc. African Geol. Surveys, Paris. 1, $304 \mathrm{pp}$.

Simon, W. et al., 1962. Leitfossilien der Mikropalaeontologie. Berlin (Borntraeger), $432 \mathrm{pp}$. 
TABLE 2

Site 135. Foraminiferal Biostratigraphy, Nature of Residue, and Important Foraminifera

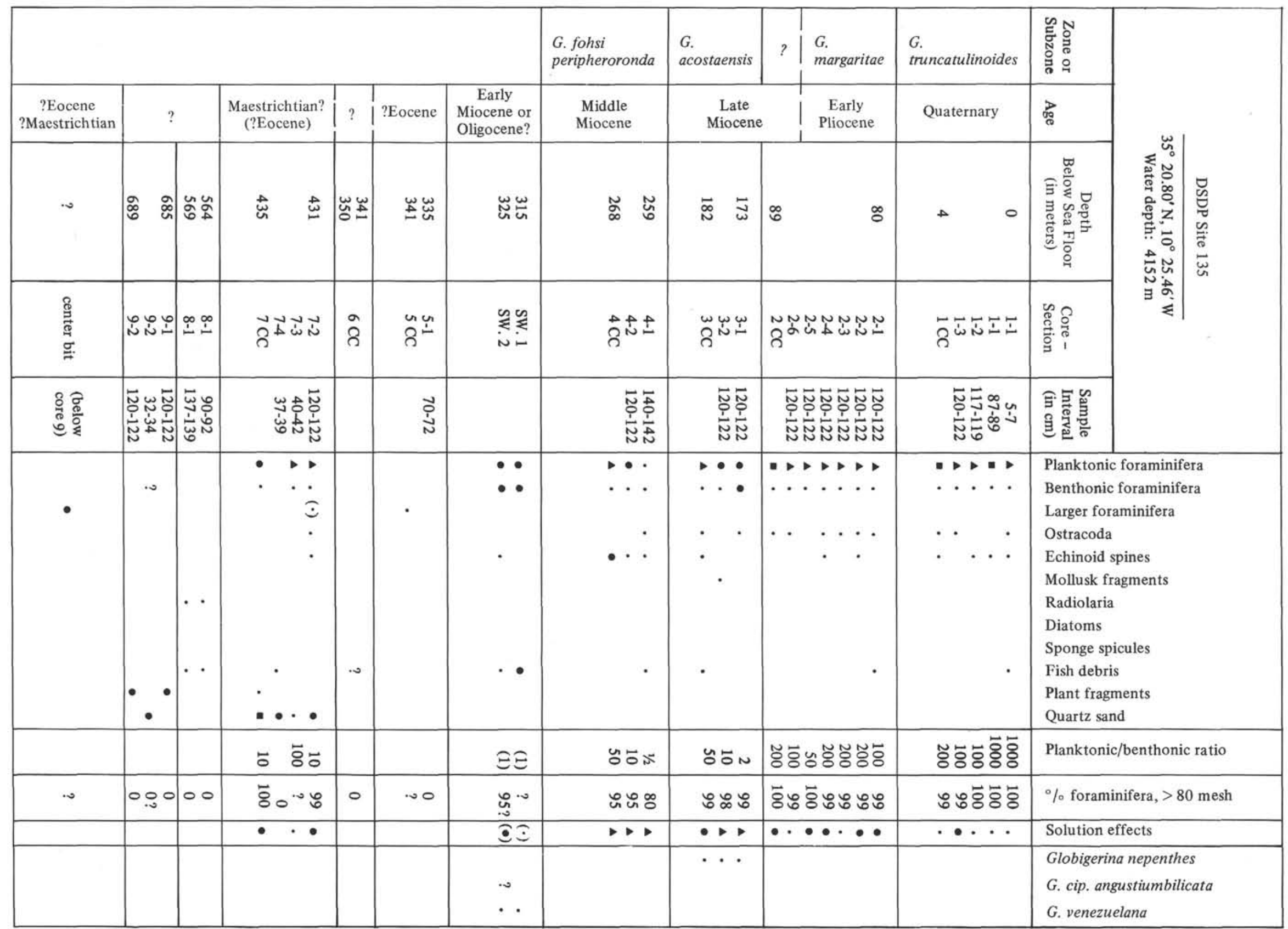




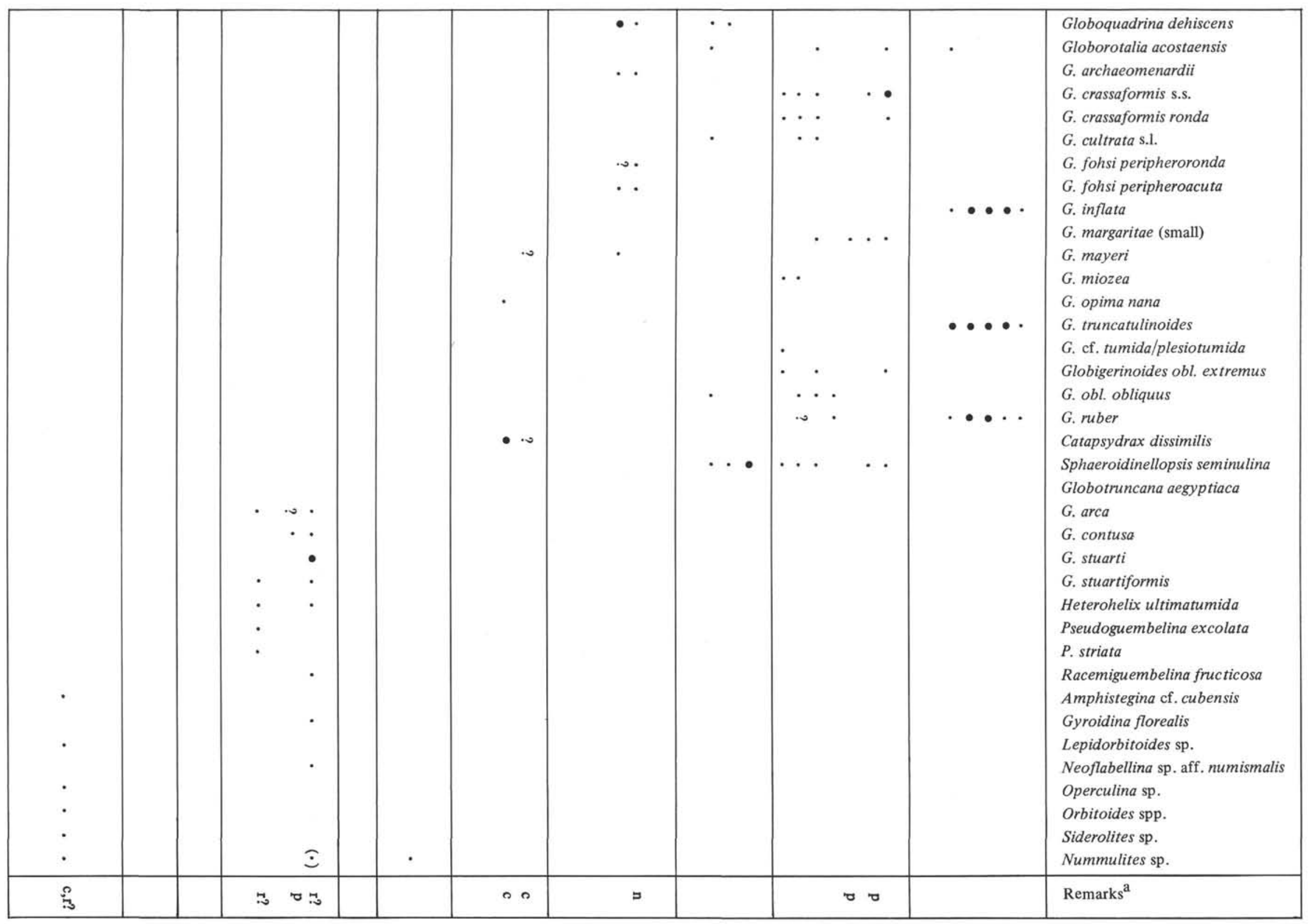

c: strong downhole contamination, $\mathrm{n}$ : foraminifera not determined, $\mathrm{p}$ : foraminifera partially determined, $\mathrm{r}$ : reworking. Symbols: _. abundant, _ common, . few . very scarce

$$
\begin{aligned}
& \text { (very strong) } \\
& \text { (strong) }
\end{aligned} \text { (moderate) } \quad \text { (weak) }
$$


TABLE 3A

Site 136, Cores 1 to 5. Foraminiferal Biostratigraphy, Nature of Residue, and Important Foraminifera

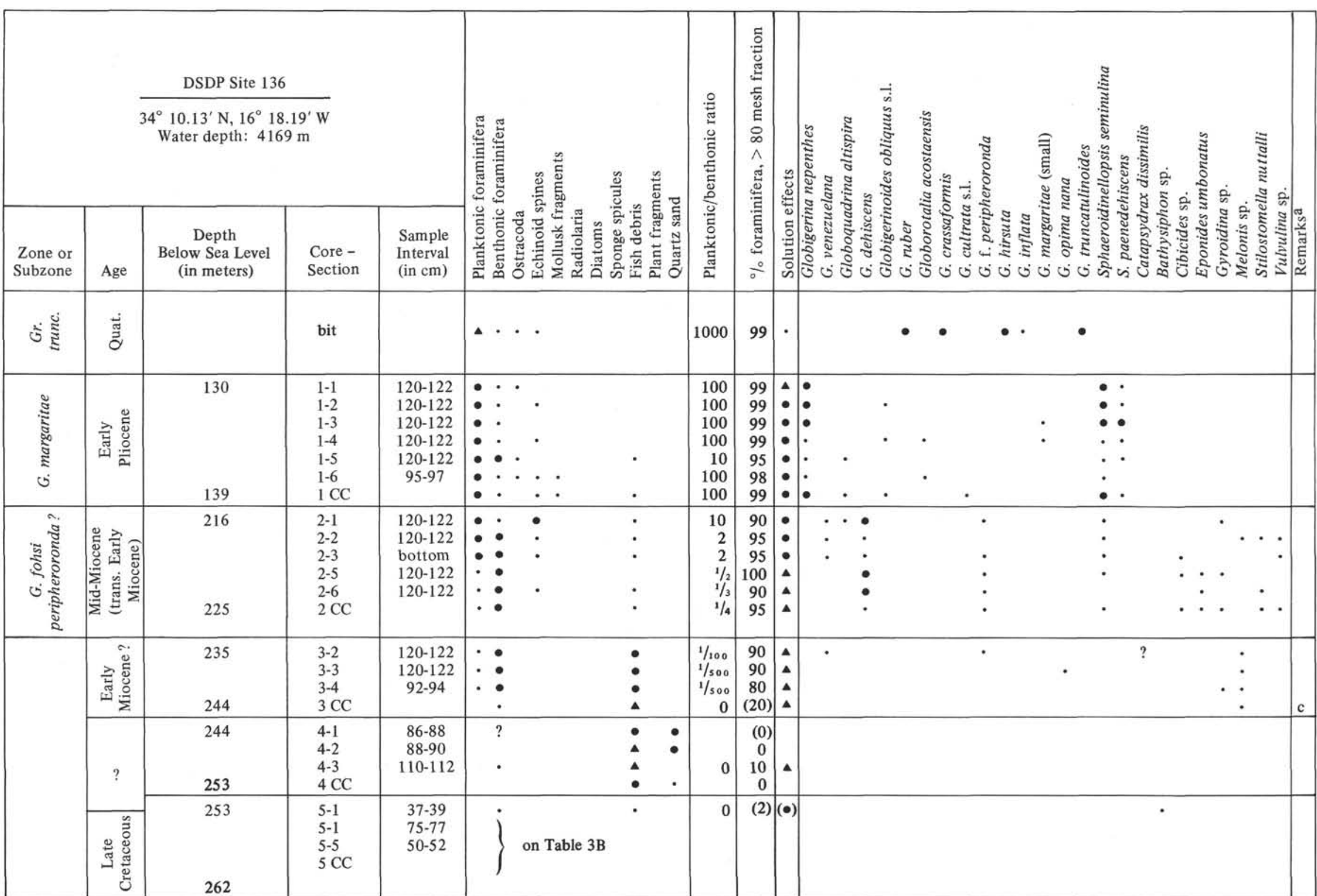

$\mathrm{a}_{\mathrm{c}}$ : strong downhole contamination
Symbols: - abundant,
common,
- few,
very scarce,
(very strong) (strong) 
TABLE 3B

Site 136, Cores 5 to 8. Foraminiferal Biostratigraphy, Nature of Residue, and Important Foraminifera

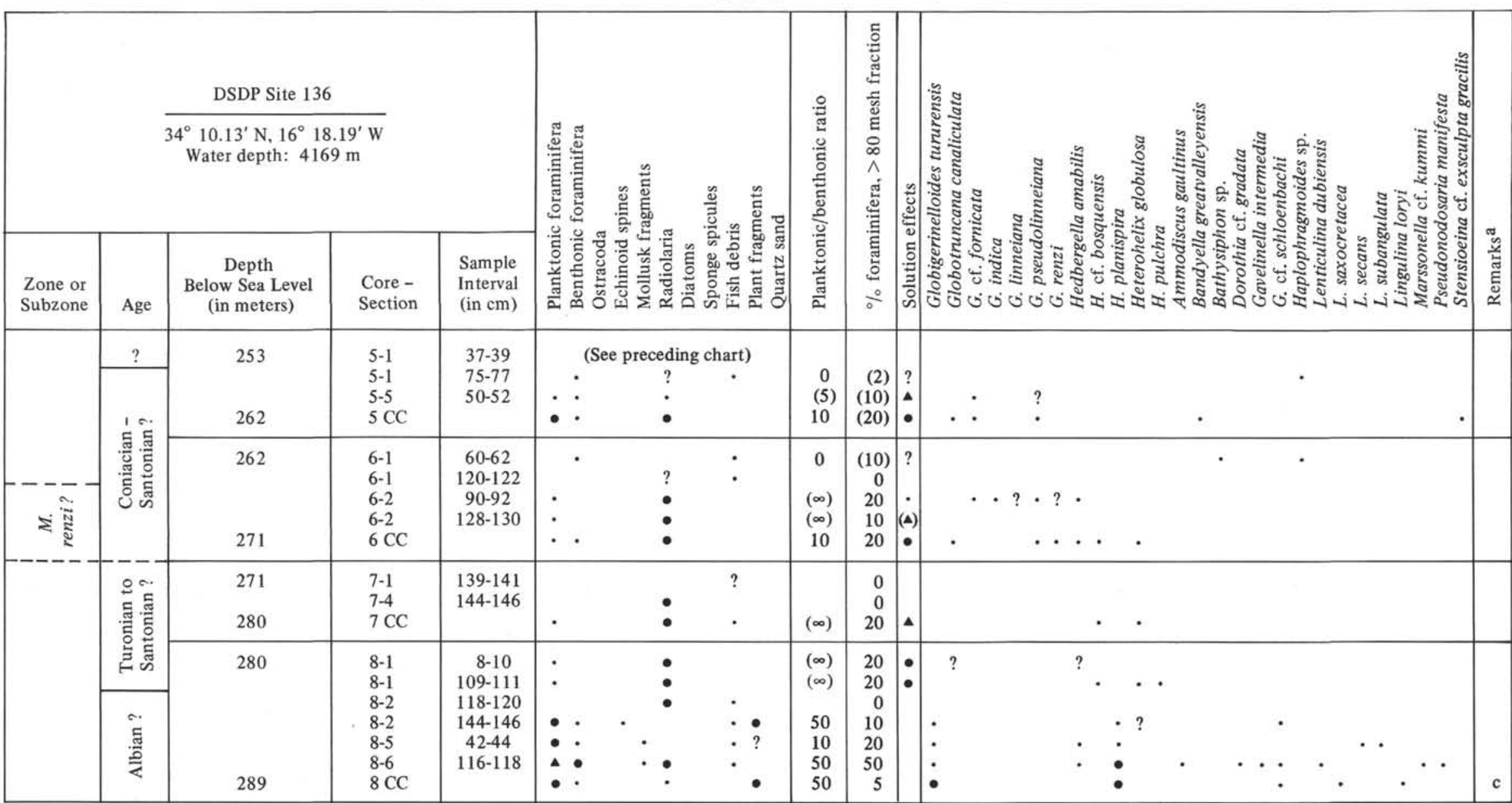

$\mathrm{a}_{\mathrm{c}}$ : strong downhole contamination.

Symbols: abundant.

$\Delta$ common,

- few,

abundant,
(very strong) $\quad \begin{aligned} & \text { common, } \\ & \text { (strong) }\end{aligned} \quad \bullet \begin{aligned} & \text { few, } \\ & \text { (moderate) }\end{aligned} \quad \cdot \begin{aligned} & \text { very scarce } \\ & \text { (weak) }\end{aligned}$ 
TABLE 4A

Site 137, Cores 1 to 7 . Foraminiferal Biostratigraphy, Nature of Residue, and Important Foraminifera

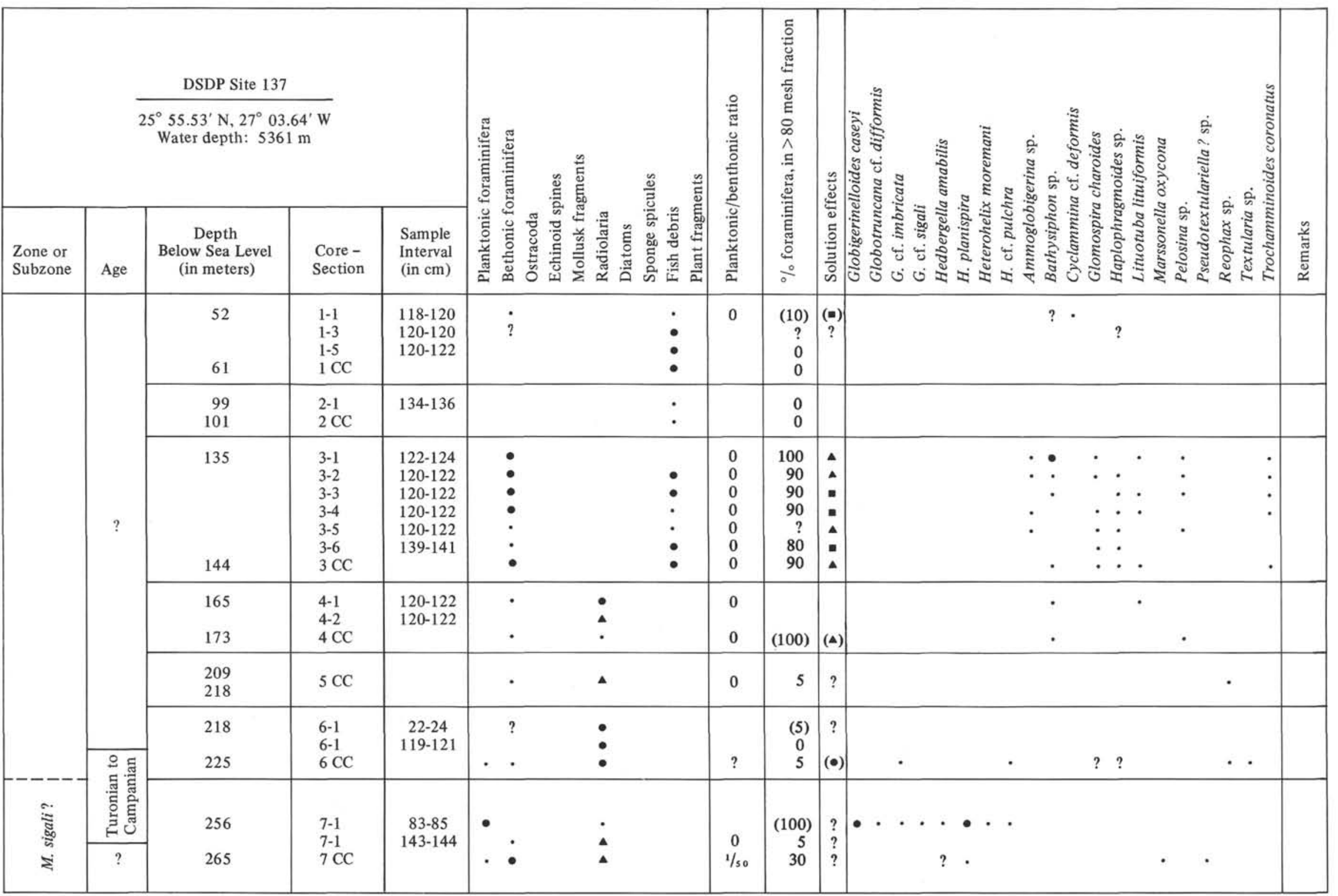

Symbols: - $\begin{aligned} & \text { abundant, } \\ & \text { (very strong) }\end{aligned} \quad \begin{gathered}\text { common, } \\ \text { (strong) }\end{gathered} \quad \bullet \begin{aligned} & \text { few, } \\ & \text { (moderate) }\end{aligned} \quad \cdot \begin{aligned} & \text { very scarce, } \\ & \text { (weak) }\end{aligned}$ 
TABLE 4B

Site 137, Cores 8-12. Foraminiferal Biostratigraphy, Nature of Residue, and Important Foraminifera

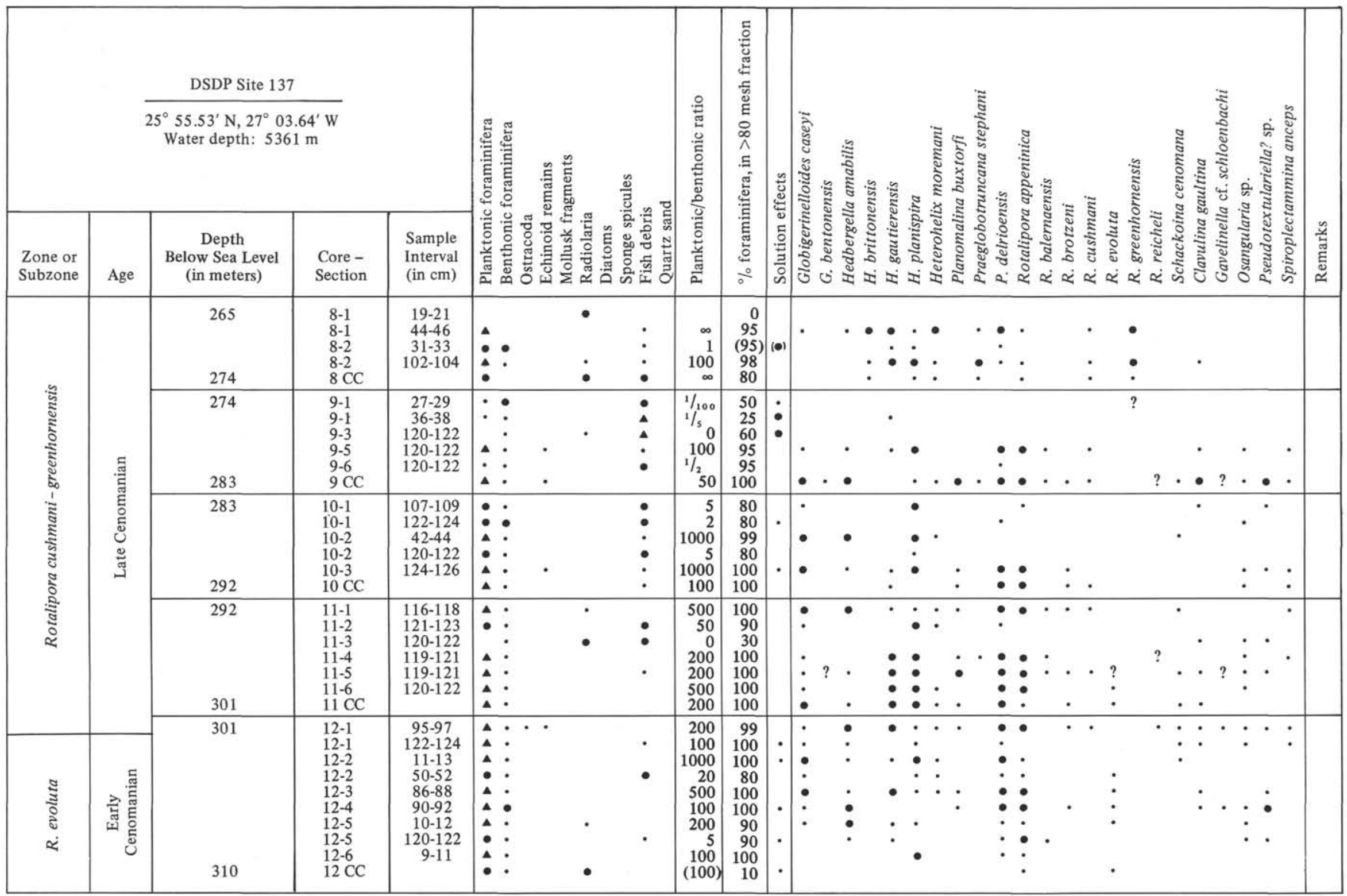


TABLE 4C

Site 137, Cores 13 to 16, SW. Core 1. Foraminiferal Biostratigraphy, Nature of Residue, and Important Foraminifera.

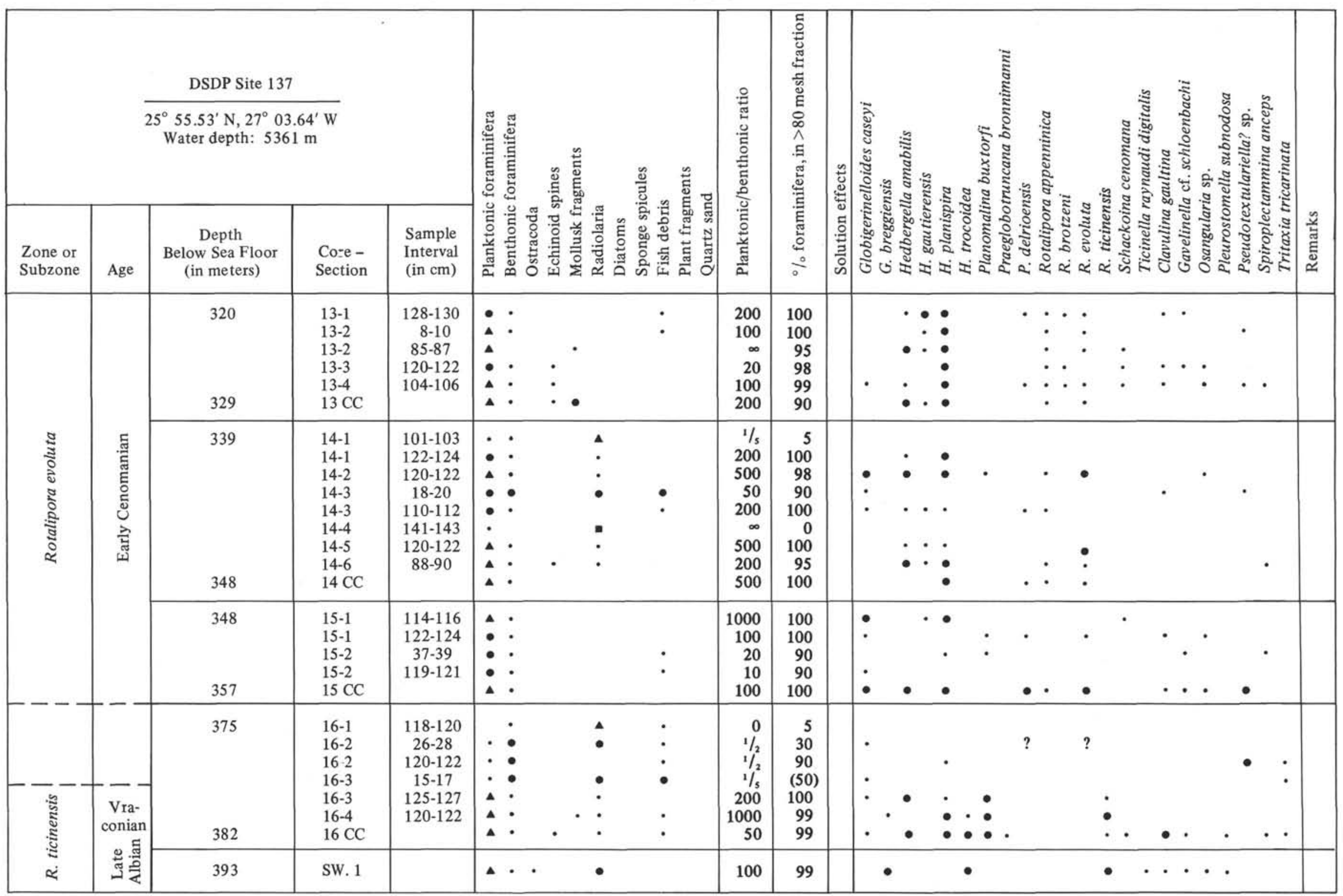

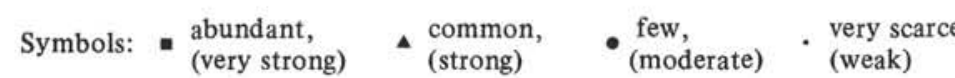


TABLE 5

Site 138. Foraminiferal Biostratigraphy, Nature of Residue, and Important Foraminifera

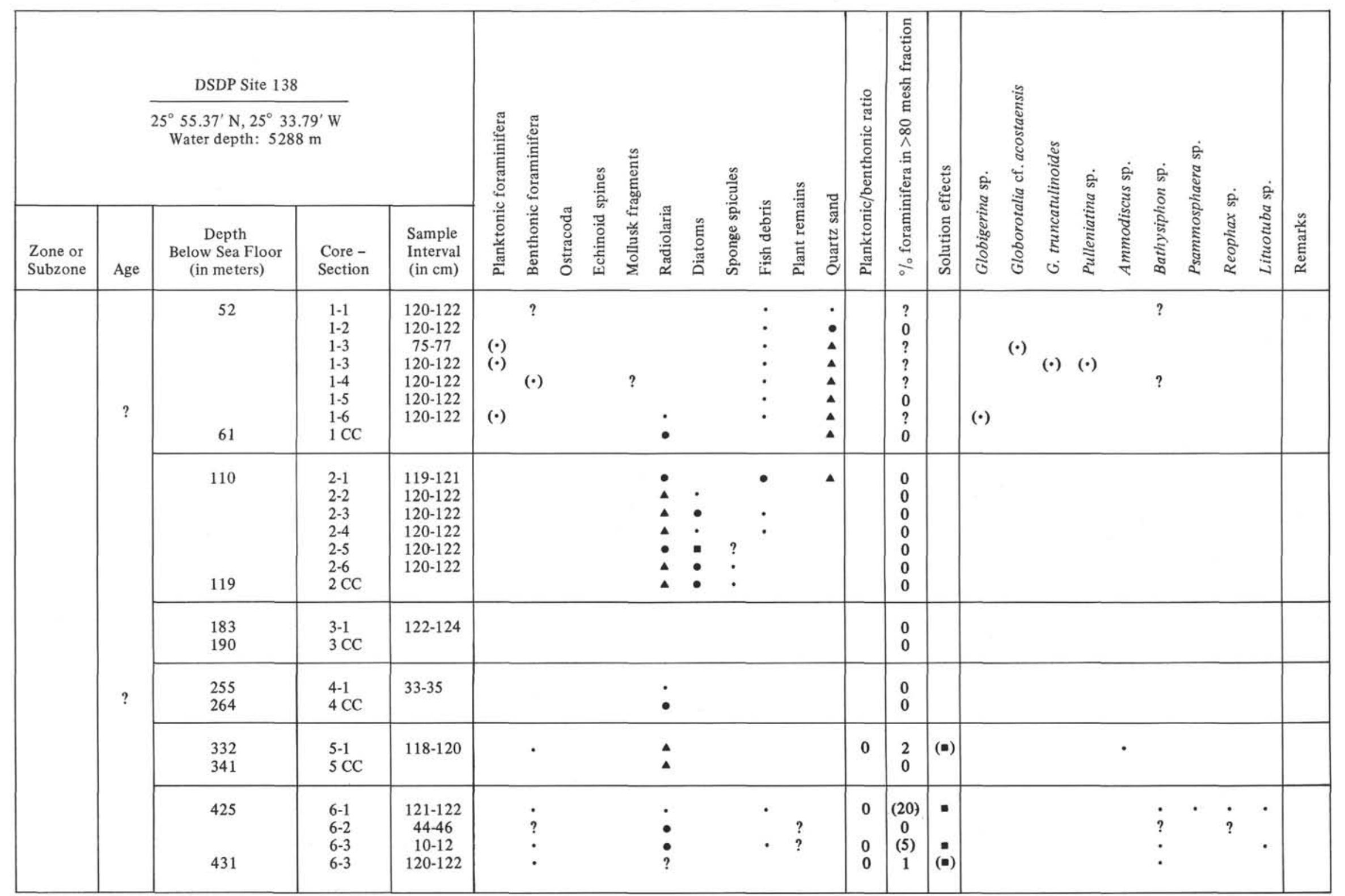

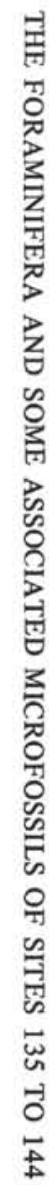


TABLE 6

Site 139. Foraminiferal Biostratigraphy, Nature of Residue, and Important Foraminifera

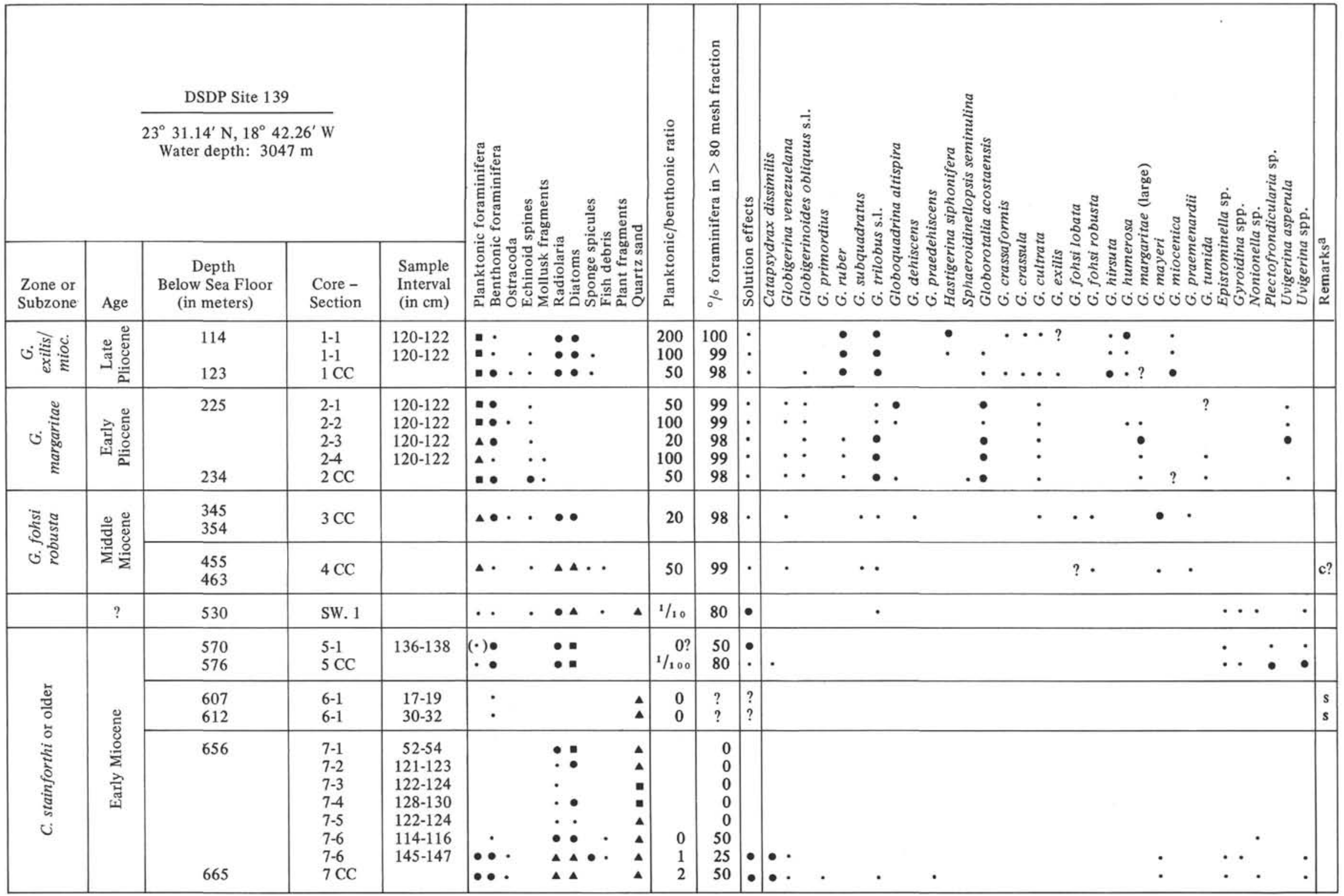

$\mathrm{a}_{\mathrm{c}}$ : strong downhole contamination, s: thin section only.

Symbols: - $\begin{aligned} & \text { abundant, } \\ & \text { (very strong) }\end{aligned}$ ^ $\begin{aligned} & \text { common, } \\ & \text { (strong) }\end{aligned} \quad \begin{aligned} & \text { few, } \\ & \text { (moderate) }\end{aligned} \quad$ very scarce 
. 
TABLE 7

Site 140. Foraminiferal Biostratigraphy, Nature of Residue, and Important Foraminifera

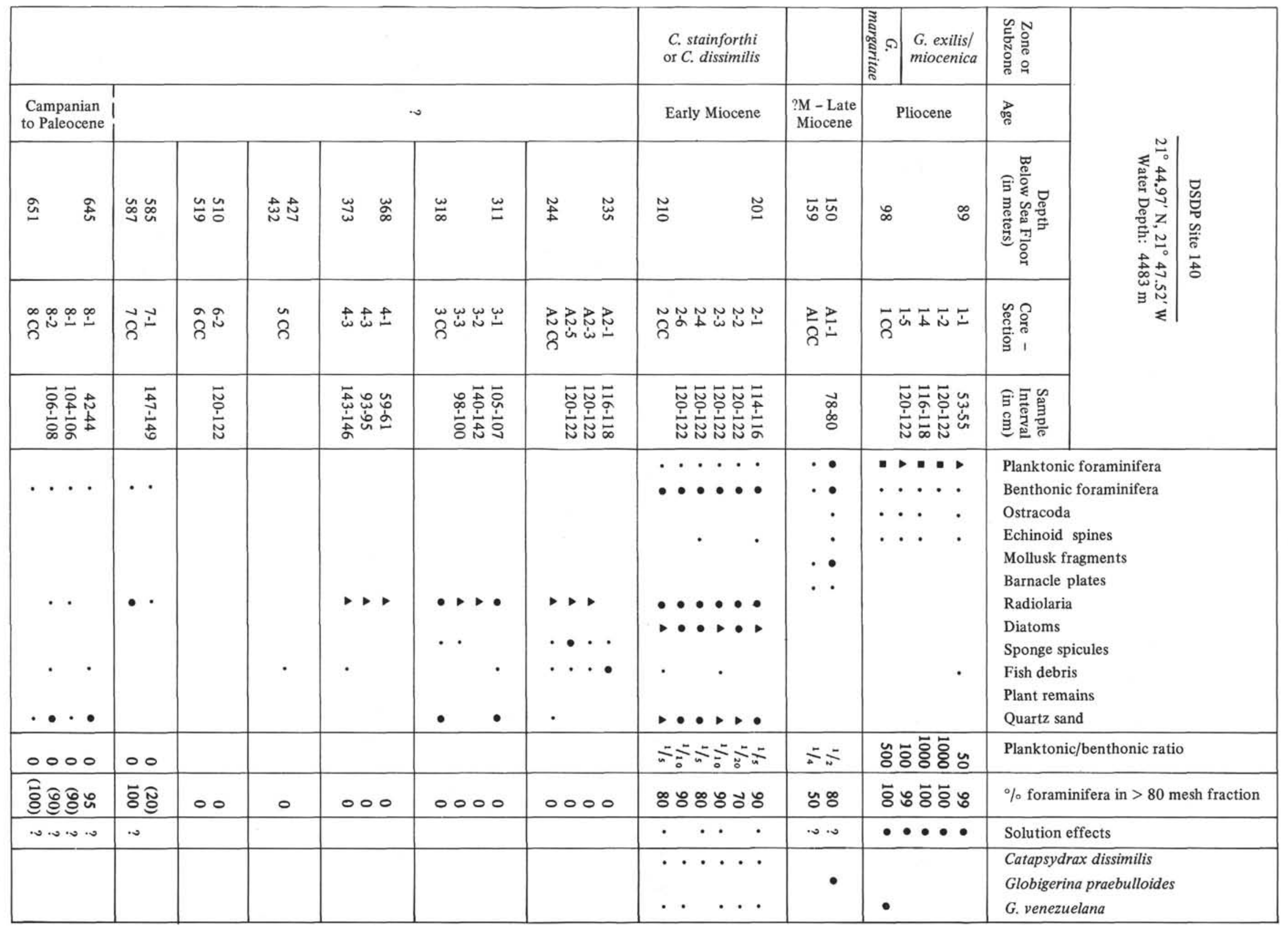




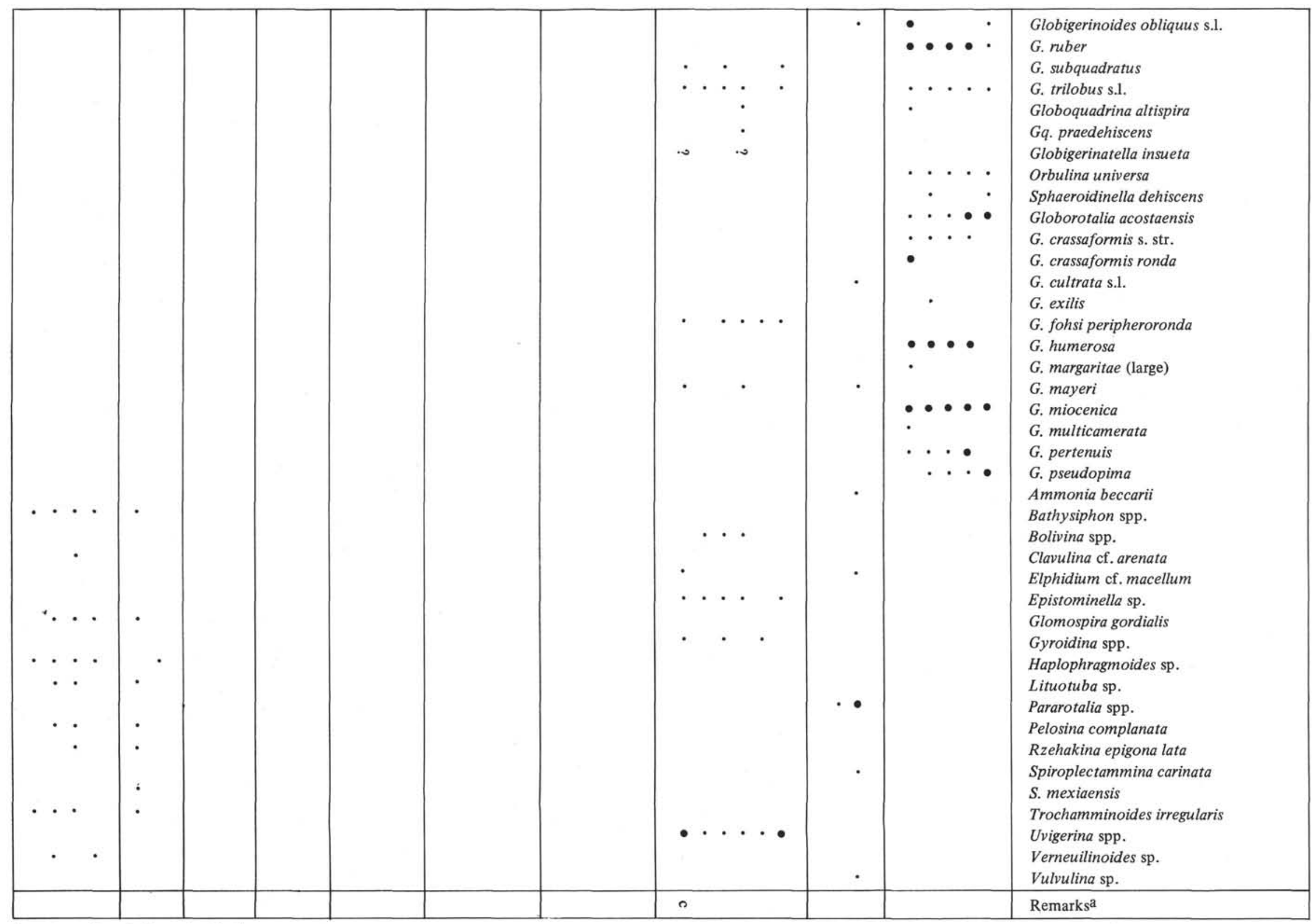

$a_{\mathrm{C}}$ : strong downhole contamination. 
TABLE 8A

Site 141, Cores 1 to 4. Foraminiferal Biostratigraphy, Nature of Residue, and Important Foraminifera

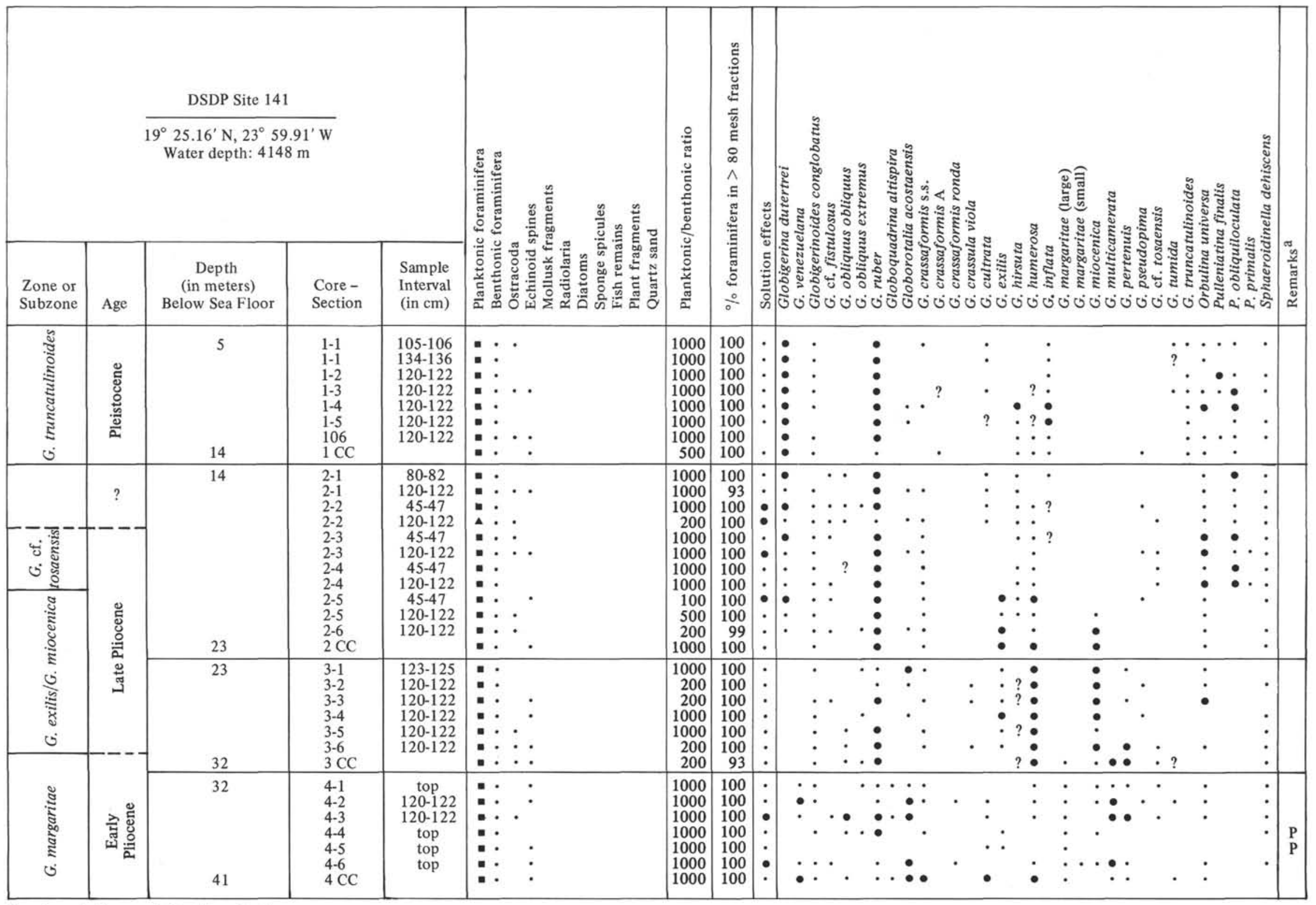

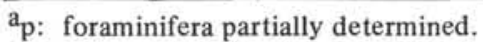

Symbols: - $\begin{aligned} & \text { abundant, } \\ & \text { (very strong) }\end{aligned} \quad \begin{aligned} & \text { common, } \\ & \text { (strong) }\end{aligned} \quad$ few, $\begin{aligned} & \text { (moderate) } \\ & \text { (weak) }\end{aligned}$ 

TABLE 8B

Site 141, Cores 5 to 9, SW. Core 1. Foraminiferal Biostratigraphy, Nature of Residue, and Important Foraminifera

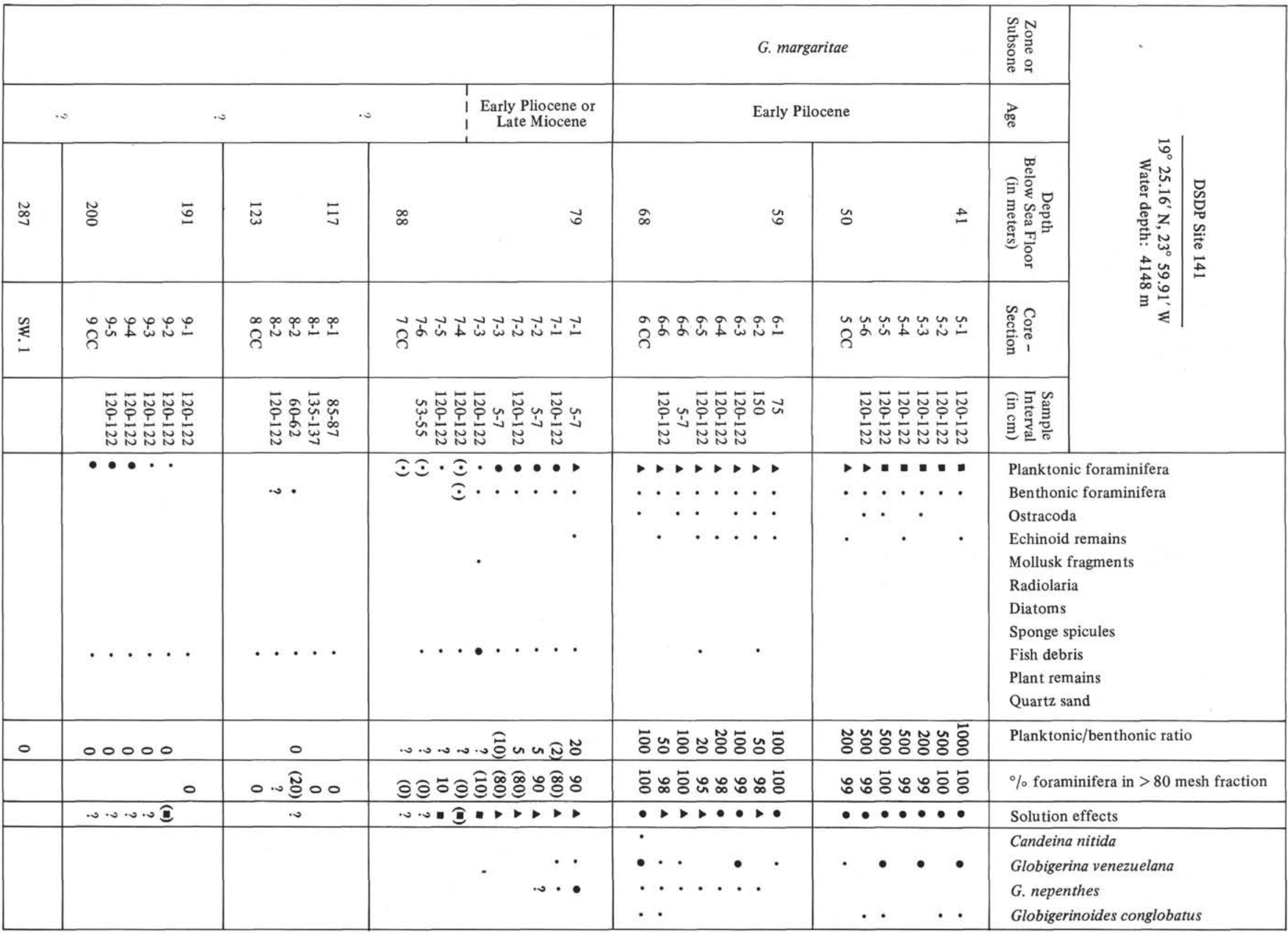




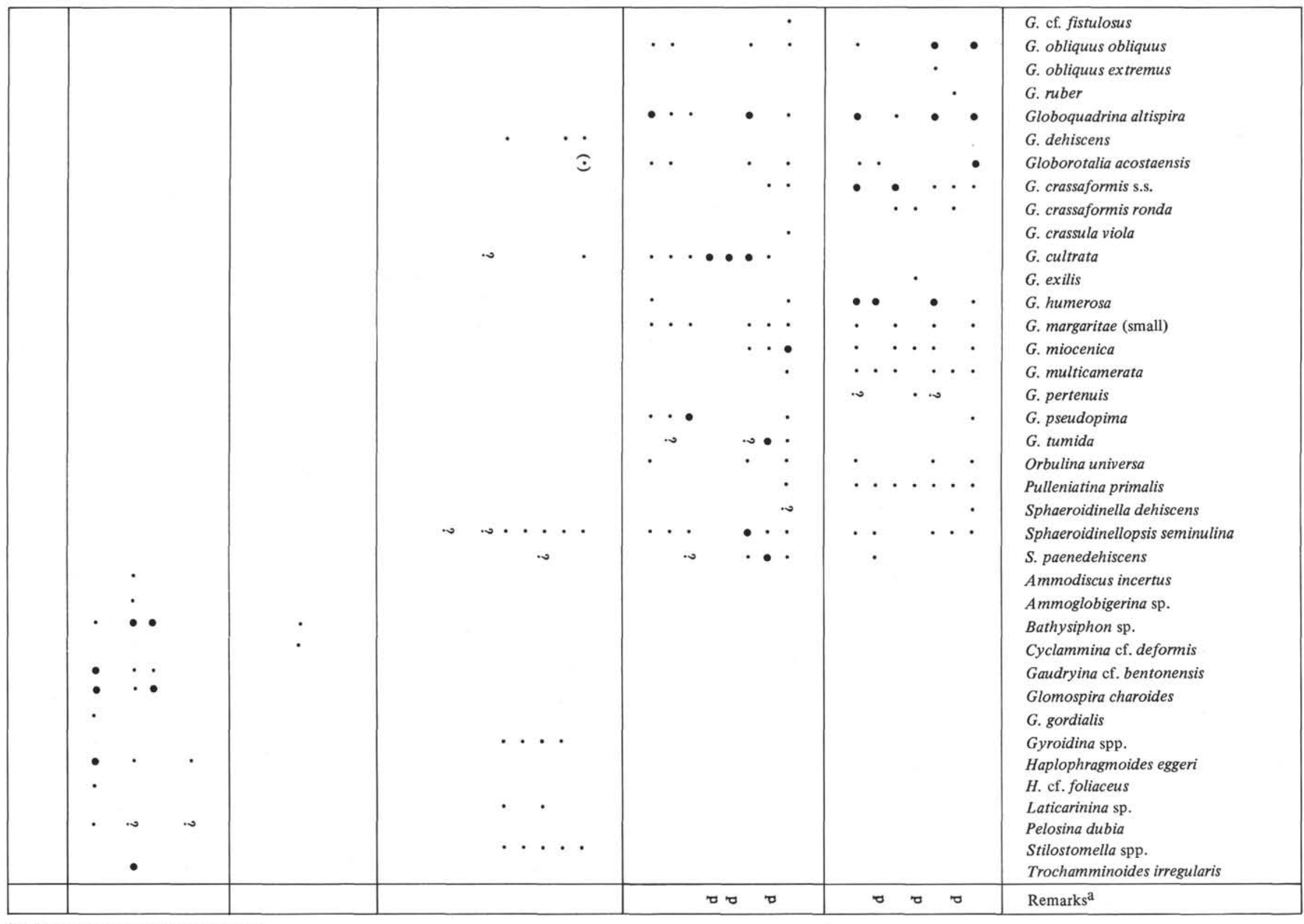

${ }^{a} \mathrm{p}$ : foraminifera partially determined. 
TABLE 9A

Site 142, Cores 1 to 5. Foraminiferal Biostratigraphy, Nature of Residue, and Important Foraminifera

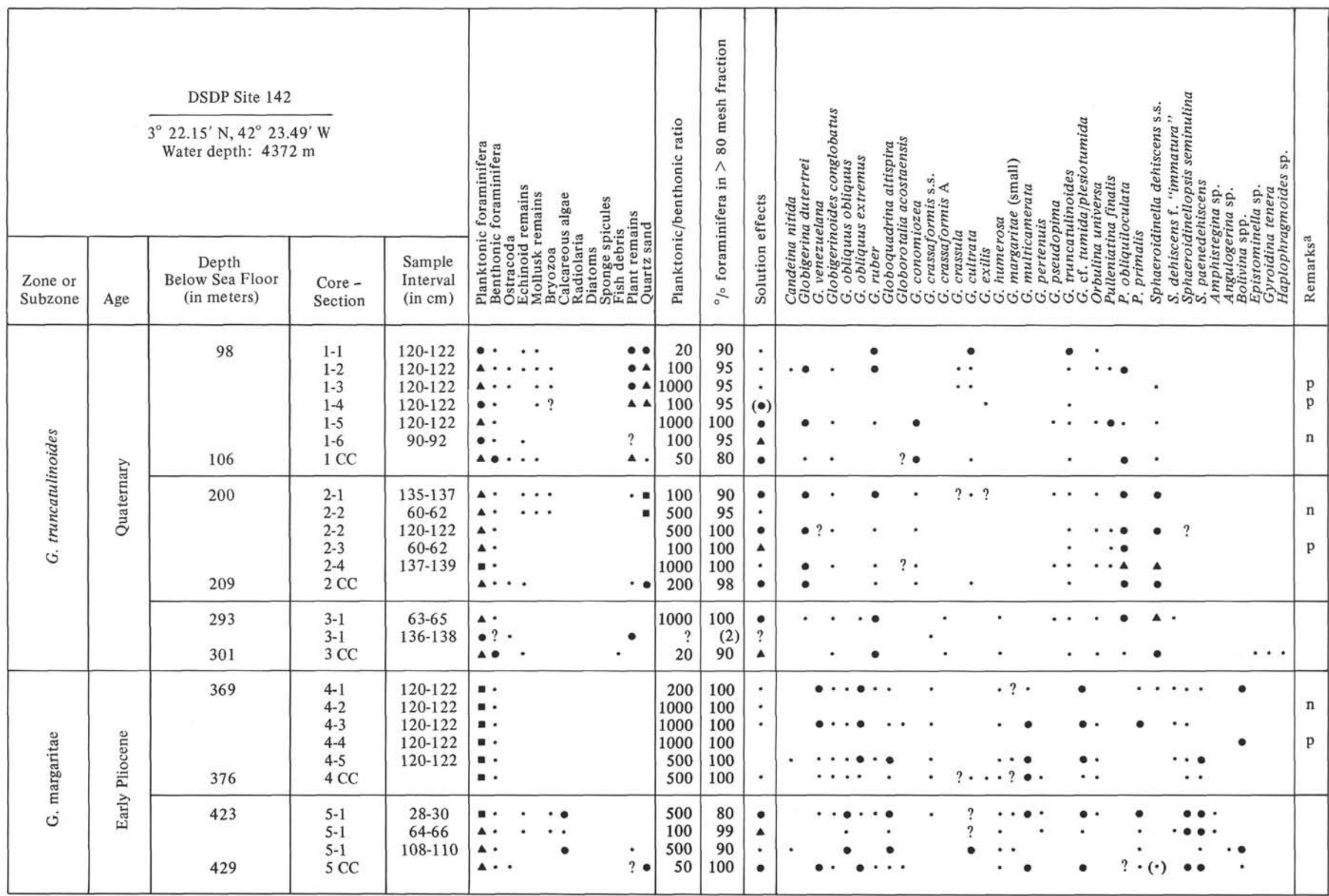

$\mathrm{a}_{\mathrm{n}}$ : foraminifera not determined; $\mathrm{p}$ : foraminifera partially determined.

Symbols: - $\begin{aligned} & \text { abundant, } \\ & \text { (very strong) }\end{aligned} \quad \wedge \begin{aligned} & \text { common, } \\ & \text { (strong) }\end{aligned} \quad \begin{aligned} & \text { few, } \\ & \text { (moderate) }\end{aligned} \quad \cdot \begin{aligned} & \text { very scarce, } \\ & \text { (weak) }\end{aligned}$ 
TABLE 9B

Site 142, Core 6 to total depth. Foraminiferal Biostratigraphy, Nature of Residue, and Important Foraminifera

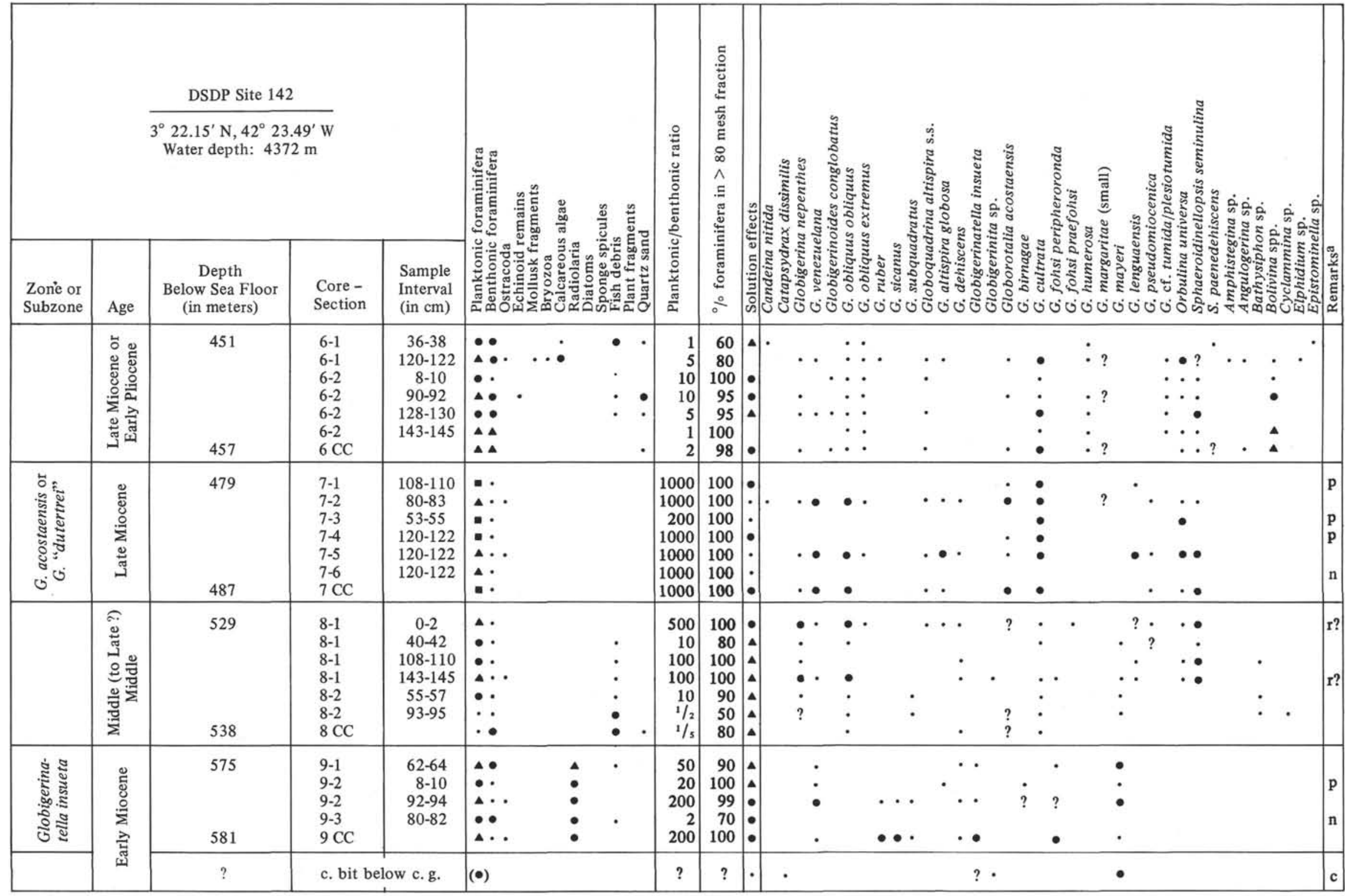

$\mathrm{a}_{\mathrm{c}}$ : strong downhole contamination, $\mathrm{n}$ : foraminifera not determined, $\mathrm{p}$ : foraminifera partially determined, $\mathrm{r}$ : reworking.

Symbols: - abundant, ^ common, - few, (very strong) very scarce 
TABLE 10

Site 143. Foraminiferal Biostratigraphy, Nature of Residue, and Important Foraminifera

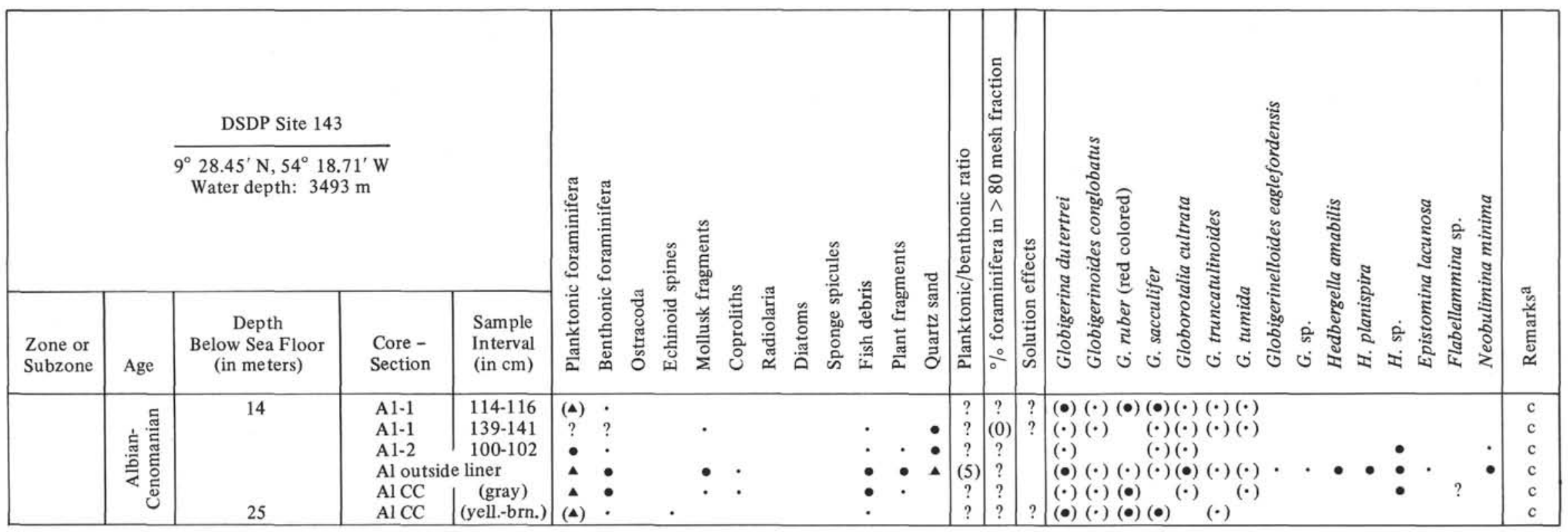

$\mathrm{a}_{\mathrm{c}}$ : strong downhole contamination.

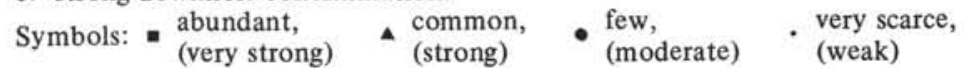



TABLE 11A

Site 144, Cores B1 to A2. Foraminiferal Biostratigraphy, Nature of Residue, and Important Foraminifera

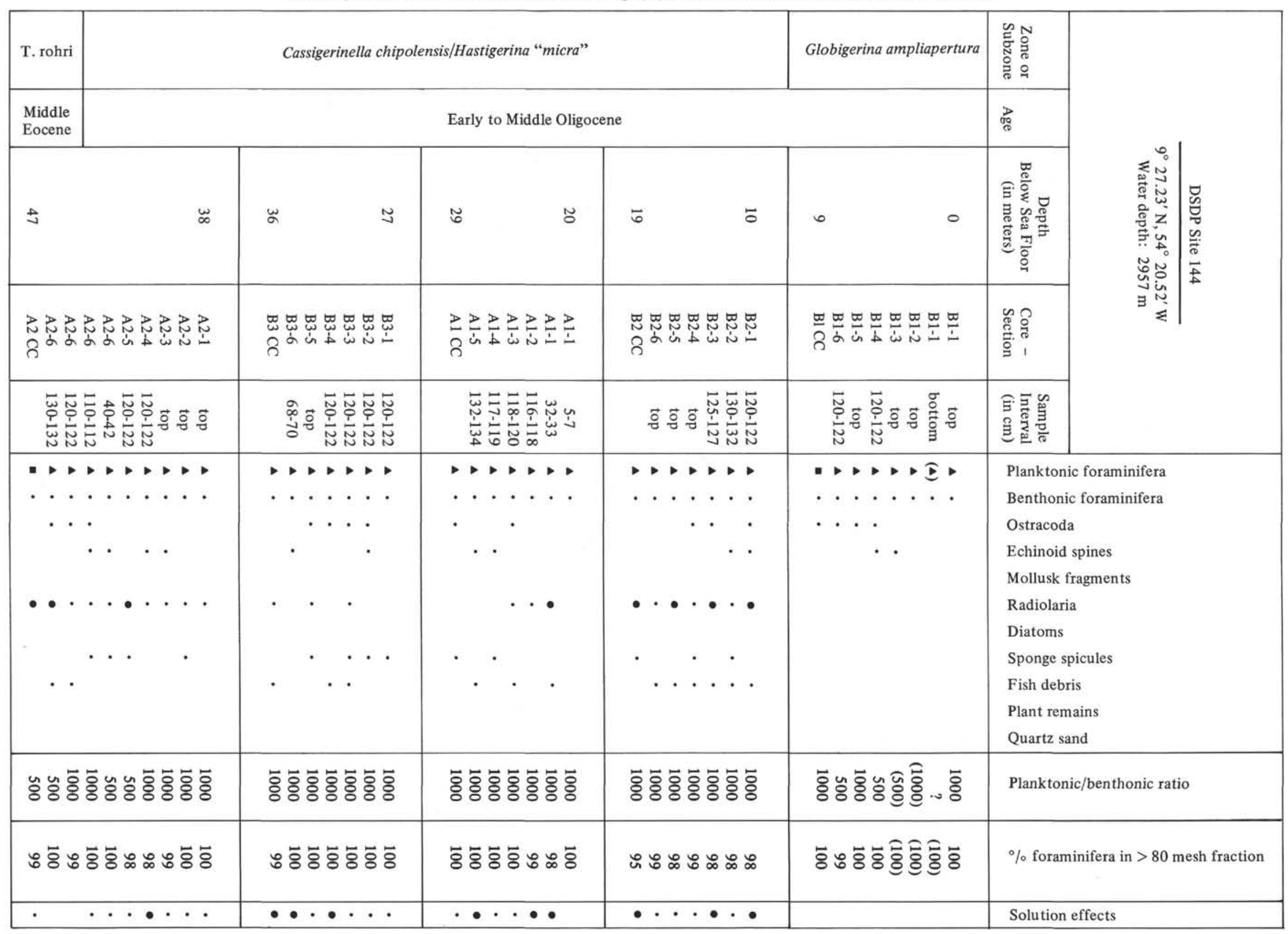




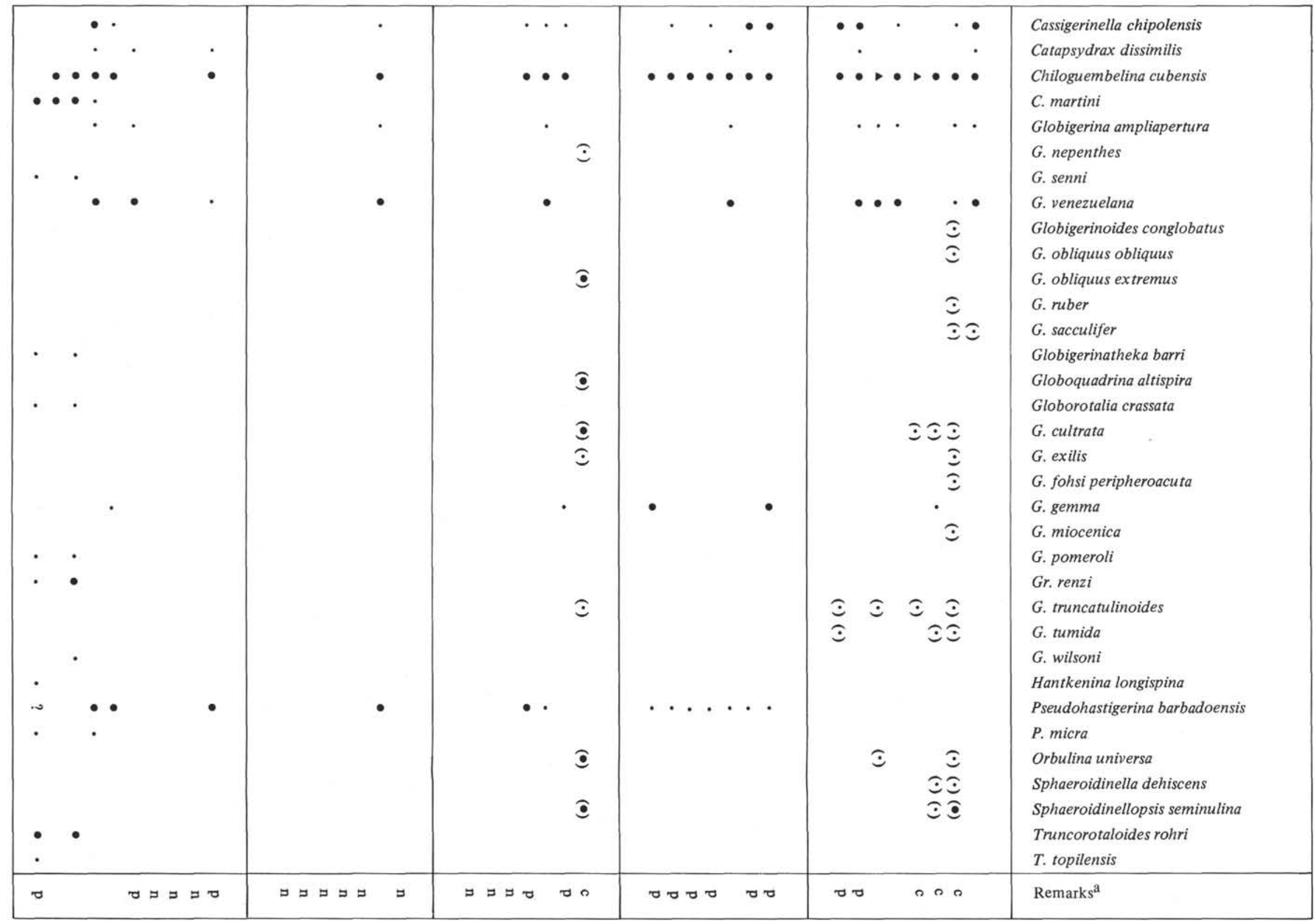

$\mathrm{a}_{\mathrm{c}}$ : strong downhole contamination; $\mathrm{n}$ : foraminifera not determined; $\mathrm{p}$ : foraminifera partially determined. 
TABLE 11B

Site 144 , Cores 1 to A4. Foraminiferal Biostratigraphy, Nature of Residue, and Important Foraminifera

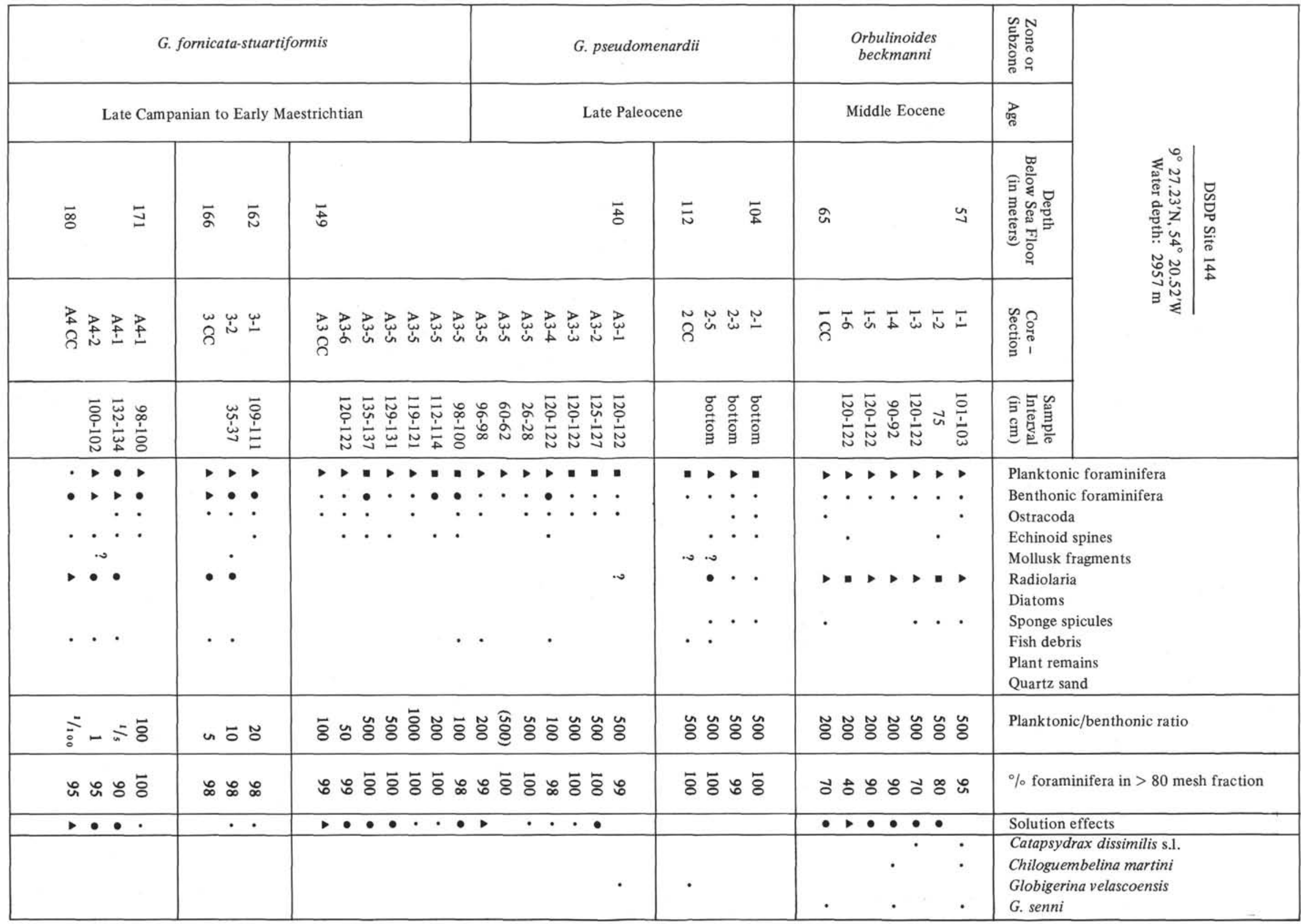




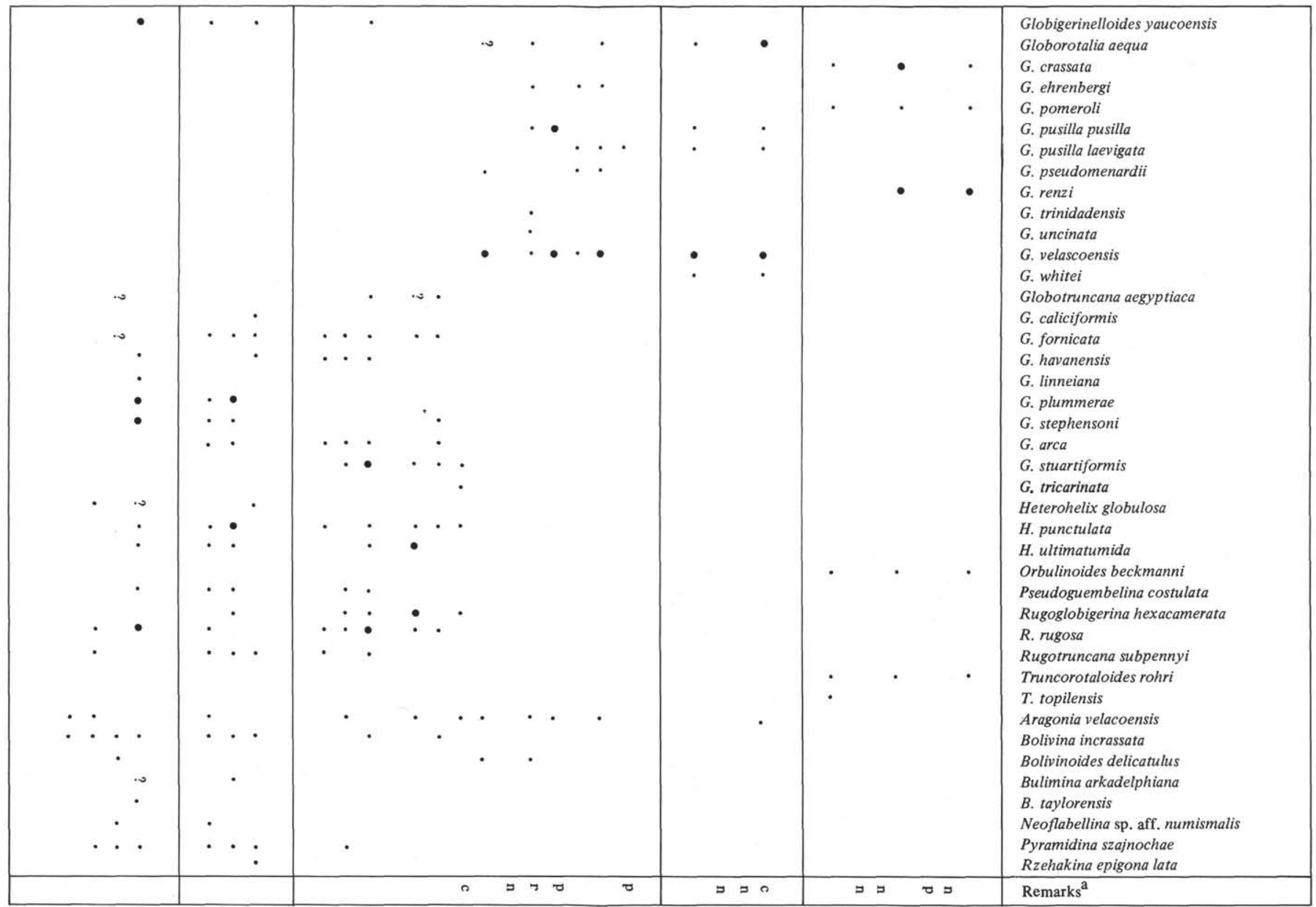

$\mathrm{a}_{\mathrm{c}}$ : strong downhole contamination, $\mathrm{n}$ : foraminifera not determined, $\mathrm{p}$ : foraminifera partially determined, r: reworking.

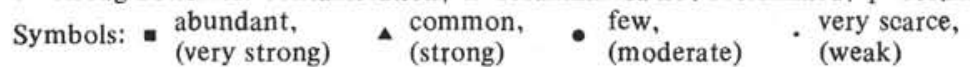


TABLE 11C

Site 144, Cores A5 to 8. Foraminiferal Biostratigraphy, Nature of Residue and Important Foraminifera

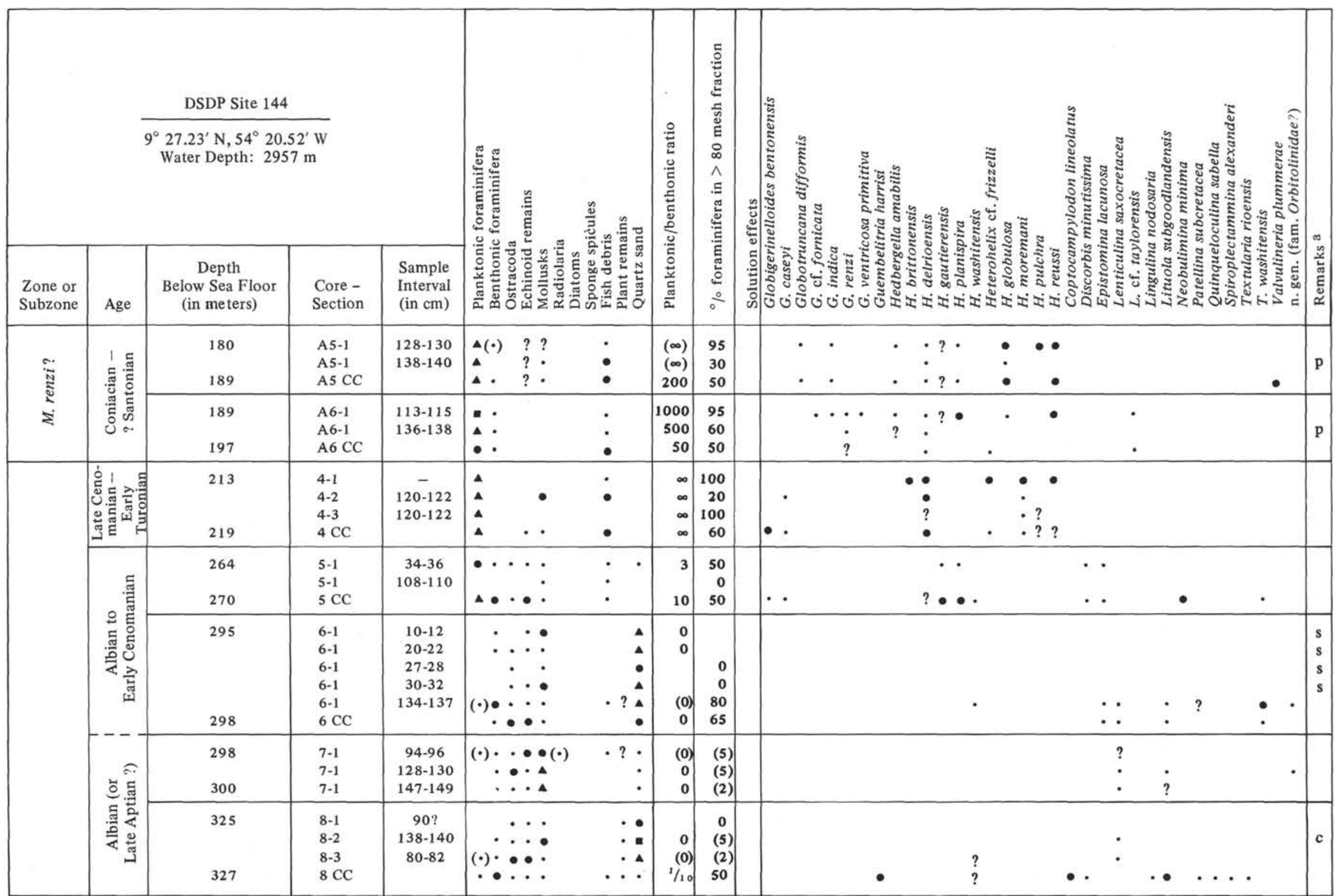

${ }^{a}$ c: strong downhole contamination, p: foraminifera partially determined, s: thin section only.

Symbols: - $\begin{aligned} & \text { abundant, } \\ & \text { (very strong) }\end{aligned} \quad \Delta \begin{aligned} & \text { common, } \\ & \text { (strong) }\end{aligned} \quad \bullet \begin{aligned} & \text { few, } \\ & \text { (moderate) }\end{aligned} \quad \cdot \begin{aligned} & \text { very scarce } \\ & \text { (weak) }\end{aligned}$ 